Journal of Educational

and Psychological Sciences

Volume (6), Issue (5): 30 Jan 2022

P: 112 - 135

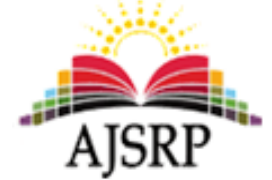

ISSN: 2522- 3399

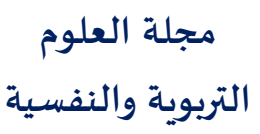

المجلد (6)، العدد (5): 30 يناير 2022 م

ص: 112 - 135

\title{
The Intermediate School Mathematics Teachers' Role in creating Professional Standards- based Learning Environments of The Education and Training Evaluation Commission from the Specialists' Perspectives
}

\author{
Ahmed Suleiman Yahya Al- Maliki \\ College of Education || University of Jeddah || KSA
}

\begin{abstract}
This research aims to identify the role of middle school mathematics teachers in creating interactive learning environments based on the professional standards of the Learning and Training Evaluation Authority from the specialists' point of view. To achieve this, the researcher used the descriptive method with its survey design. The research sample included (120) individuals, (5) teaching Staff Members of curricula and mathematics, and (19) educational supervisors in the mathematics department in Makkah Directorate of education. The role of the middle school mathematics teacher in creating interactive learning environments based on the professional standards of the Education and Training Evaluation Authority from the point of view of specialists came with a degree of (approval). The arrangement of the axes was descending as follows: (the use of modern technology in teaching mathematics, strategies for teaching mathematics, the time teaching mathematics effectively, the use of mathematical communication) for all axes $(4,24,4,47,4,47,4,50)$. There is statistically significant difference at the level of significance (0.05) between the averages of the specialists' responses according to the job title (teacher, educational supervisor, faculty member) due to the effective use of modern technology for mathematics and teaching mathematics effectively, and it reached $(5,275,5,93)$. There is statistically significant difference at the level of significance (0.05) between the averages of the specialists' responses according to the job title (teacher, educational supervisor, faculty member) due to the use of mathematics teaching strategies and using the mathematical communications, and it reached $(6,749,7,434)$. There is a statistically significant difference at the level of significance (0.05) between the averages of the specialists' responses according to the academic qualification (BA, MA, and $\mathrm{PhD}$ ). There is a statistically significant difference at the level of (0.05) between averages of responses attributed to years of experience, at the role of mathematics teacher in using modern technology and strategies for teaching mathematics, the time of effectively teaching mathematics, mathematical communication reached $(13,863,17,806,14,356,9,548)$. The researcher recommended a number of recommendations, including strengthening professional practices related to creating interactive learning environments and providing educational supervisors with the proposed vision that came out of this study in promoting an interactive educational environment.
\end{abstract}

Keywords: mathematics teachers- mathematics- practices for creating interactive learning environments.

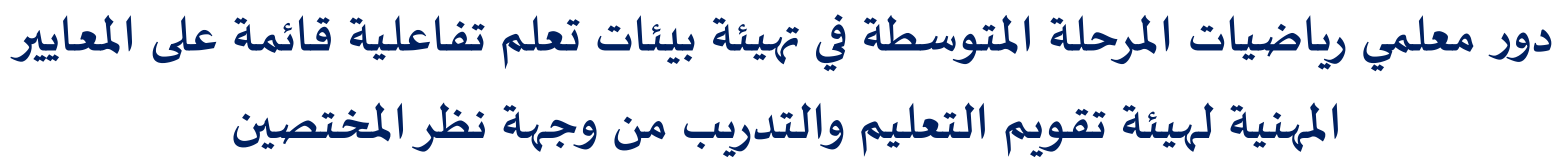

أحمد سليمان يحيى المالكي 
كلية التربية || جامعة جدة || المملكة العربية السعودية

المستخلص: هدف البحث للتعرف على دور معلمي رياضيات المرحلة المتوسطة في تهيئة بيئات تعلم تفاعلية قائمة على المعايير المهنية لهيئة تقويم التعليم والتدريب من وجهة نظر المختصين، ولتحقيق هذا استخدام المنهج الوصفي بأسلوبه المستحي، واشتملت عينة البحث على (130) مفردة؛ منهم (106) معلماً للرياضيات بالمرحلة المتوسطة، وعلى (5) عضيو تدريس المناهج وتدريس الرياضيات، وعلى (19) مشرفا تربويا بقسم الرياضيات بإدارة ومكاتب تعليم مكأ وتم التوصل إلى النتائج التالية:

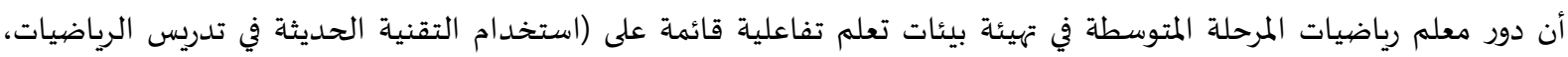

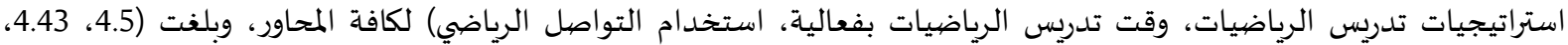

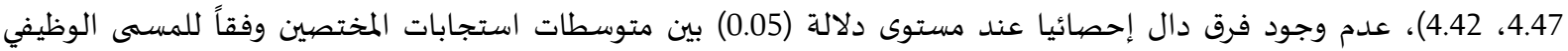

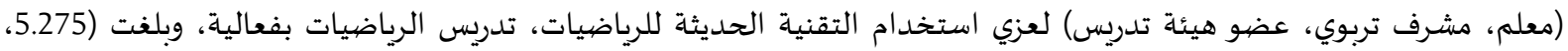

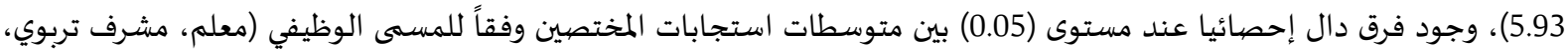

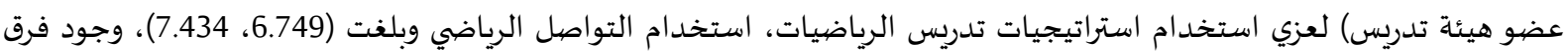

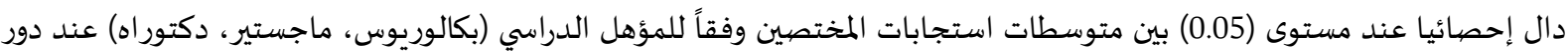

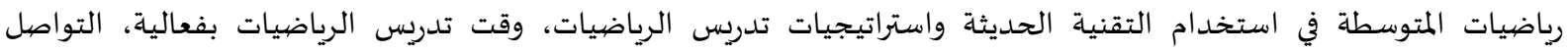
الرياضي، بلغت (7.772، 9.978.7.008، 7.155)، وجود فرق دال إحصائيا عند مستوى (0.05) بين متوسطات استيات استجابات الميات المختصيين

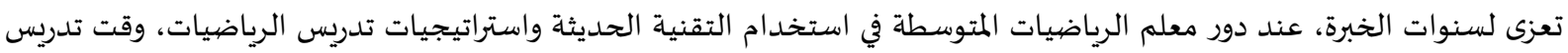

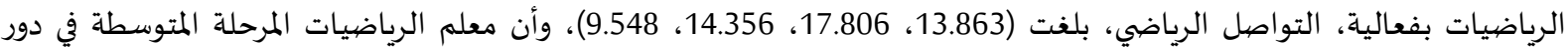

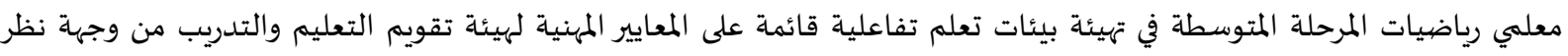

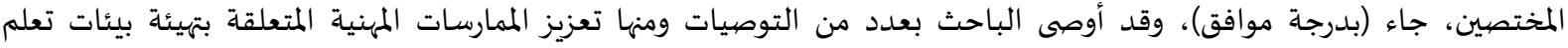
تفاعلية وتزويد المشرفين التربويين بالتصور مقترح الذي خرجت به هذه الدراسة في سبيل تعزيز بيئة تعليمية تفاعلية.

مقدمة الدراسـة.

تشهد المملكة العربية السعودية تطورا كبيرا في المنظومة التعليمية سواء على مستوى التخطيط أو التطوير، وذلك في كافة مراحلها وقد انطلقت رؤيتها المستقبلية (2030) التي تهدف إلى تحسين استقطاب المعلمين وتأهليهم وتطويرهم، وكذلك إلى تحسين البيئة التعليمية المحفزة للأبداع والابتكار، مما قد يساهم في تنمية التحصيل

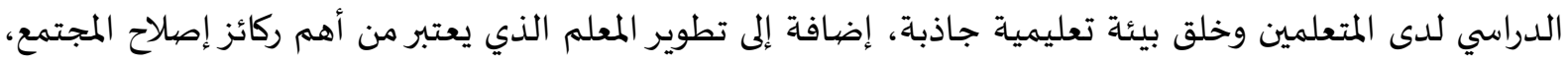
وما يقوم به من دور رئيسي في العملية التعليمة. وقد اعتمد مجلس إدارة هيئة تقويم التعليم والتدريب في عام (2017) المعايير المهنية للمعلمين التي تهدف إلى جودة التعليم المقدم للطلاب وتحسين تعلمهم، وتعزيز دور المعلمين ورفح تأهيلهم، والتشجيع على تنمية المهارات

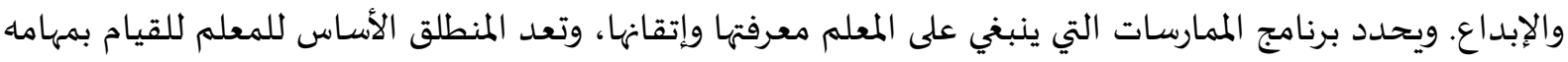

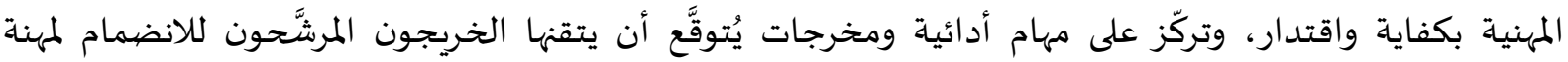

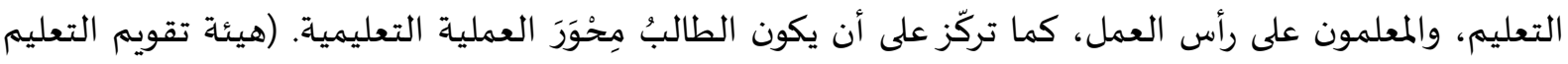
والتدريب، 2017).

وتأسيسا على ما سبق، قام المركز الوطني للقياس والتقويم بوزارة التعليم في عام (2017) بإعداد المعايير

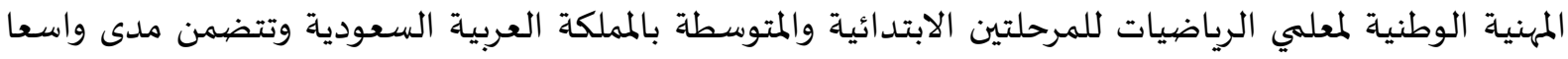

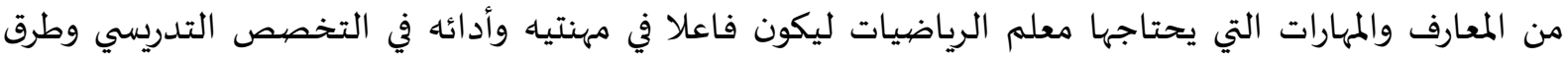
تدريسا،، بحيث يمثل في ممارساته وسلوكياته الدور المأمول. (المركز الوطني للقياس والتقويم، 2017). 
وكما نصت عليه أهداف التعليم لعام 2020م أن أحد أهدافها تحسين البيئة التعليمية المحفزة للإبداع والابتكار، ولأهمية البيئة التعليمة في الممارسات التدريسية فقد وضعت هيئة تقويم التعليم والتدريب معيارا أساسيا

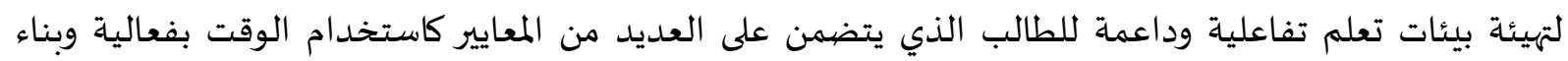
ثقافة تواصل معززة للتعلم وتوظيف الاستراتيجيات والتقنيات الحديثة (وزارة التعليم، 2017).

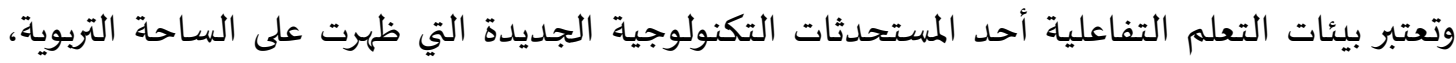

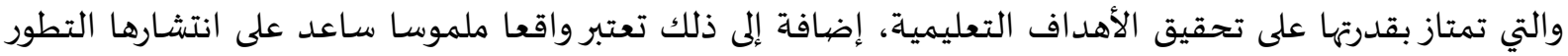

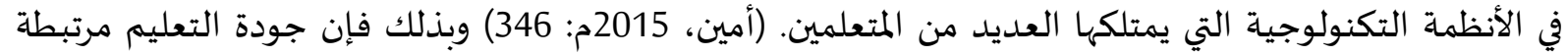

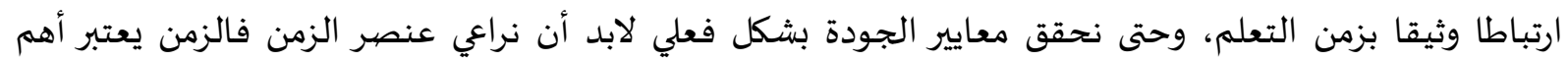

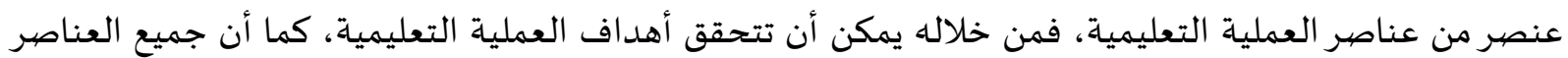

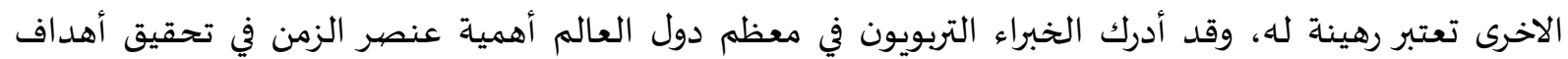

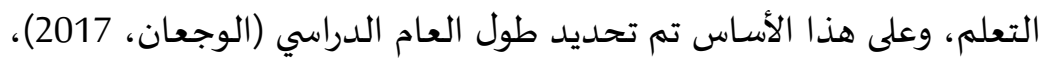
وكذلك نجد أن للتفاعل الصفي النشط- الذي يستند على تخطيط تربوي سليم- دورا رئيسا في تحقيق

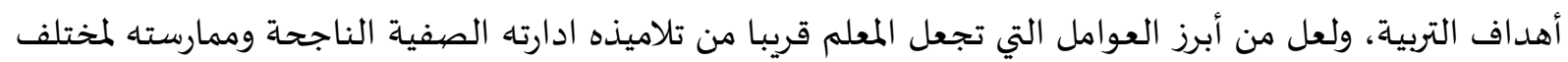

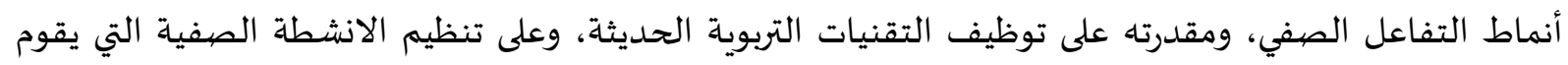
بها تلاميذه داخل غرفة الصف، والتي خطط لها لكي يحدث تغيرا محمودا في سلوكهم وفي طرائق تفكيرهم. بحيث

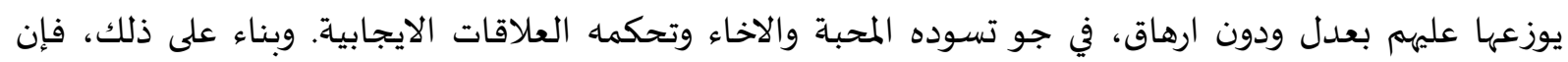

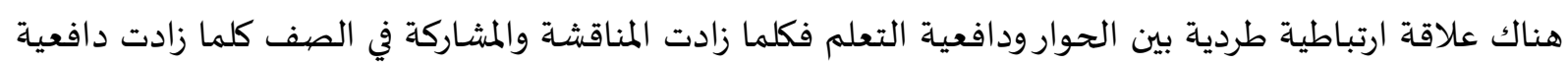

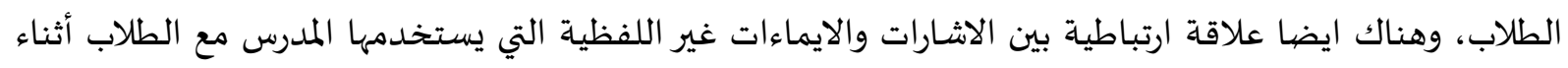

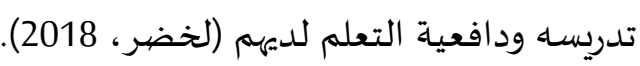
وارتكازا على ما سبق، اعتمدت العديد من الدراسات على بحث أوجه التقصير لدى لدى معلمي الرياضيات، فقد أشار بيومي (2019) إلى أن واقع الممارسات الصفية لمعلمي الرياضيات بالمرحلة الابتدائية في ضوء المعات المعايير المهنية

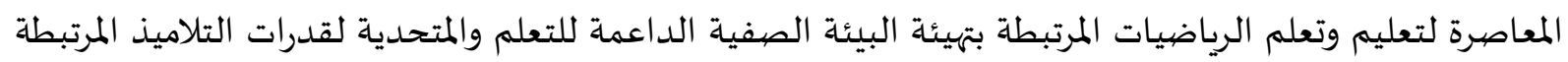

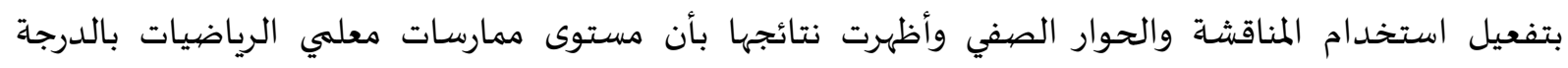

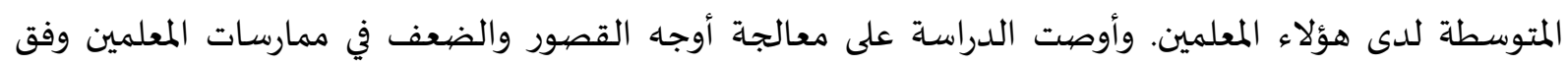

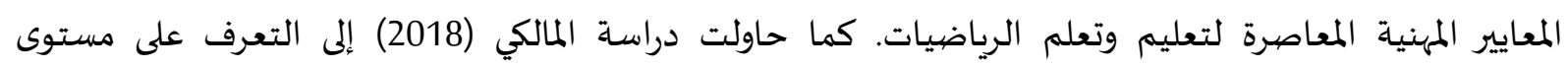

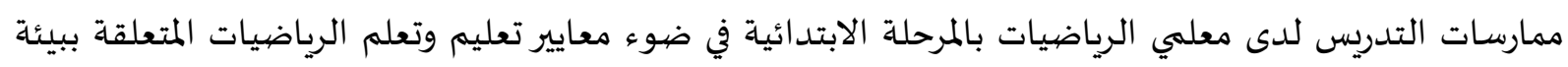

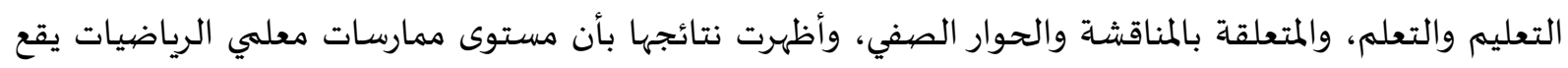
في المستوى المتوسط للأداء التدريسي.

وفي السياق نفسها، حاولت دراسة العمري (2018) التعرف على مستوى الممارسات التدريسية لدى معلمي

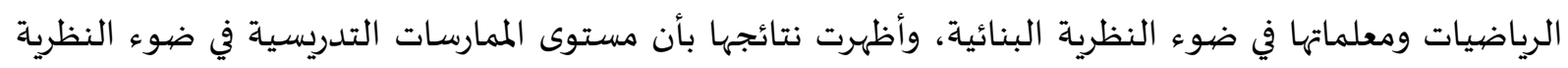

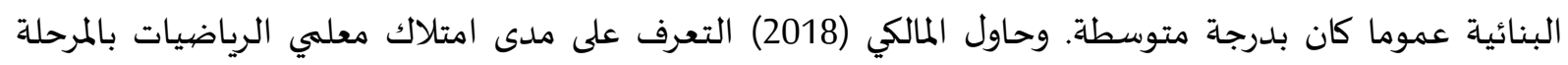

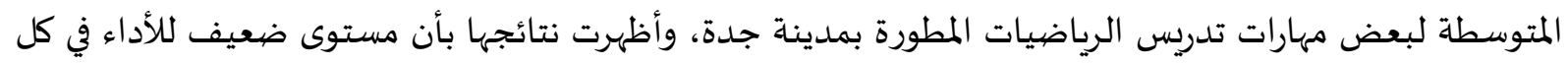

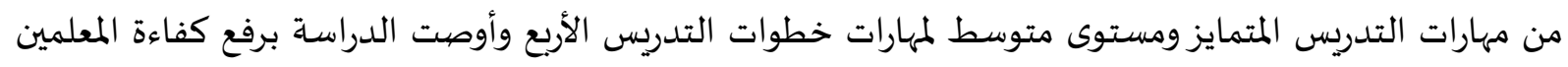

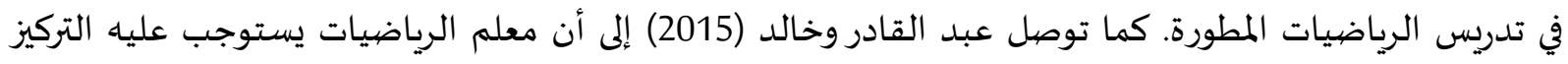

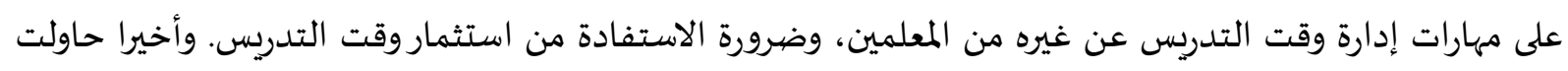


دراسة الأمين (2019) الكشف عن أسباب ضعف مستوى التحصيل في مادة الرياضيات لدى طلاب الصف الثاني

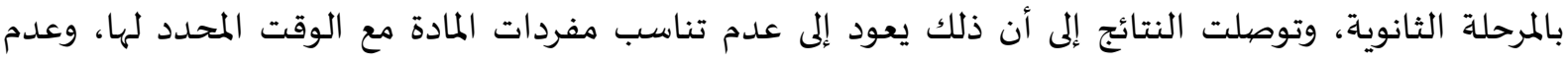

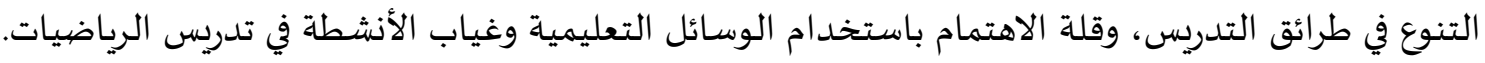

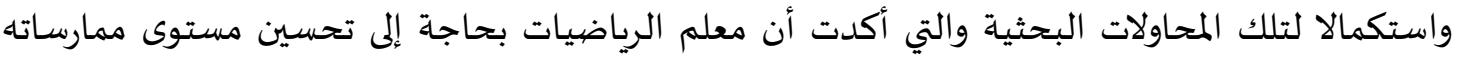
التدريسية، فإن البحث الحالي يستهدف الكشف عن دور معلمي رياضيات المرحلة المتوسطة في تهيئة بيئات تعلم تفاعلية قائمة على المعايير المهنية ومن ثم بناء تصور مقترح لتفعيل هذا الدور وفقا للمعايير المهنية لهيئة تقويم تلمئي التعليم والتدريب بالمملكة العربية السعودية من وجهاة نظر المختصين.

مشكلة الدراسـة وتساؤلاته: نظرا لأهمية البيئة التعليمية وما تقوم به وزارة التعليم من جهود كبيرة فقد اطلقت برنامج التحول الوطني

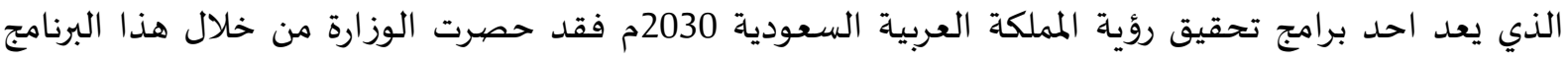

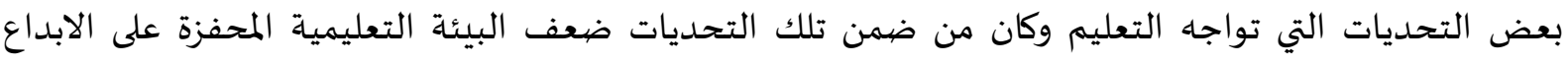

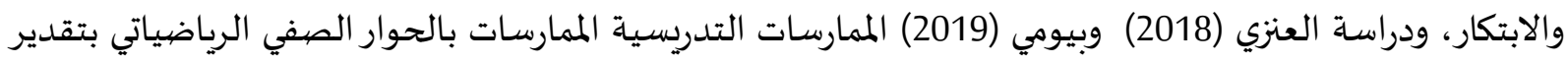

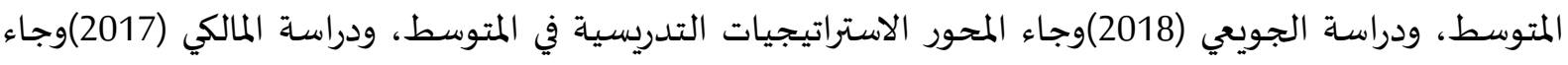
التخطيط لكفايات التخطيط للدروس اليومية في المتوسط. من خلال ما سبق يتضح وجود قصور لدى أداء معلمي رياضيات في تهيئة بيئات تعلم تفاعلية وذلك ما لماتيطات

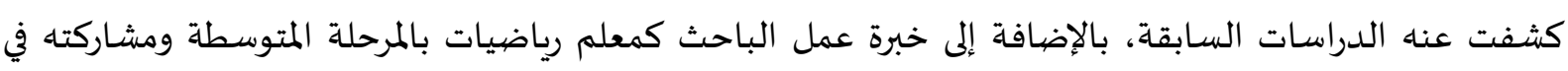

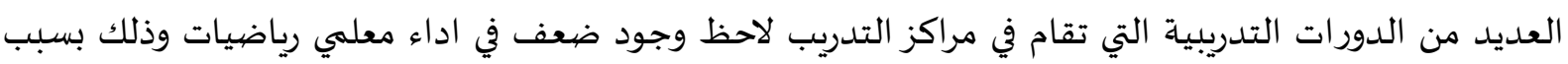

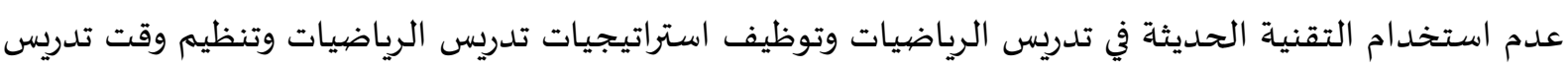
الرياضيات بفعالية واستخدام التواصل الرياضي. ومن جهة اخرى، كشف العديد من مشرفي ومختصي رياضيات المرحلة المتوسطة أثناء مقابلتي لهم، بان فئان

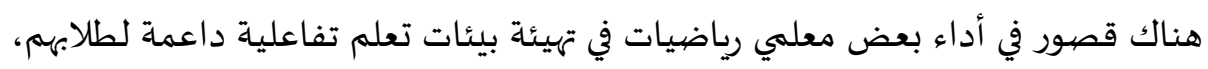
مشيرين أن هذا القصور يعود على استخدم طرق وأساليب قديمة، وعدم استثمار الوقت في اكمال

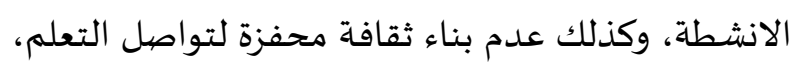

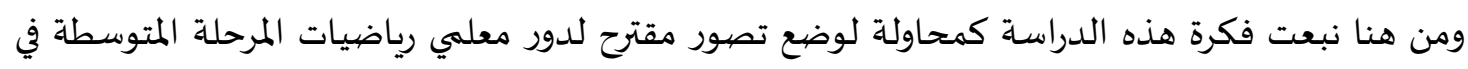

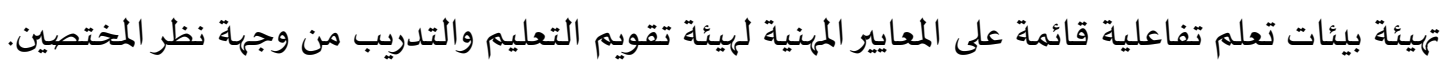
وتسعى هذه الدراسة الحالية إلى الإجابة عن الأسئلة الاتية: ما دور معلمي رياضيات المرحلة المتوسطة في تهيئة بيئات تعلم تفاعلية في ضوه هاءه معايير هيئة تقويم التعليم والتدريب بالمملكة العربية السعودية من وجهة نظر المختصين؟

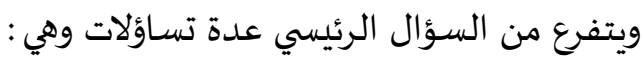
1- ما دور معلم رياضيات المرحلة المتوسطة في استخدام التقنية الحديثة في تدريس الرياضيات من وجهات نظر المختصين؟ ما دور معلم

2- ما دور معلم رياضيات المرحلة المتوسطة في توظيف استراتيجيات تدريس الرياضيات من وجهة نظر المختصين؟

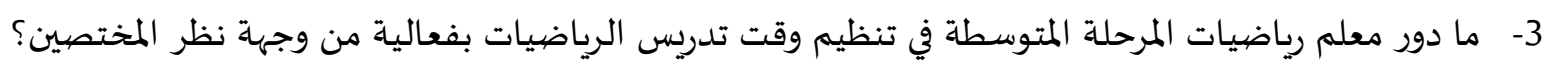

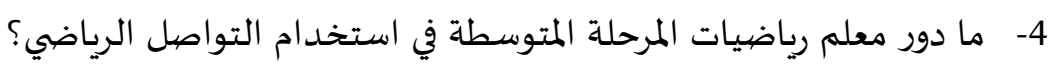


أهداف الدراسة Objectives of the study:

هدفت الدراسة الحالية إلى تحقيق الآتي:

1- التعرف على دور معلم رياضيات المرحلة المتوسطة في استخدام التقنية الحديثة لتدريس الرياضيات.

2- التعرف على دور معلم رياضيات المرحلة المتوسطة في توظيف استراتيجيات تدريس الرياضيات.

3- التعرف على دور معلم رياضيات المرحلة المتوسطة في تنظيم وقت تدريس الرياضيات بفعالية

4- التعرف على دور معلم رياضيات المرحلة المتوسطة في استخدام التواصل الرياضي.

أهمية الدراسة The importance of studying:

تحددت أهمية الدراسـة الحالية من خلال الجوانب الآتية:

أ- أل الأهمية النظرية:

1- تساهم الدراسة في مساعدة معلمي الرياضيات في تهيئة بيئات تعلم تفاعلية وداعمة لطالب أثناء العملية

التعليمية وأثرها على التحصيل الدراسي.

2- تساعد المشرفين على تحديث البرامج التدرببية المقدمة حاليا وفق تهيئة بيئات تعلم تفاعلية وداعمة للطالب.

3- تقدم هذه الدراسة مجموعة من المقترحات، وذلك للاستفادة منها للباحثين لإجراء دراسات متشابهة في تهيئة

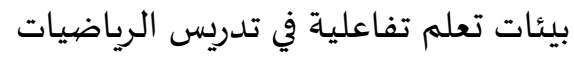

4- تعد هذه الدراسة من الدراسات التي اهتمت بدور معلم الرياضيات في تهيئة بيئات تعلم تفاعلية قائمة على

المعايير المهنية من وجهة نظر المختصين.

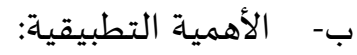

1- تعد هذه الدراسة استجابة للأهداف التعليمية 2020، والابحاث والدراسات السابقة حول دور معلم

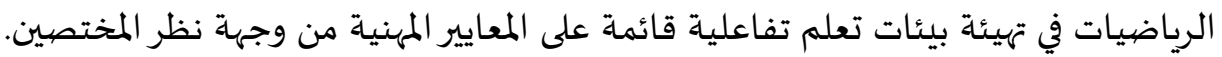

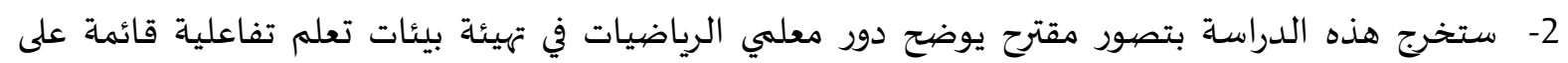

المعايير المهنية من وجهاج نظر المختصين.

3- تكشف نتائج هذه الدراسة جوانب القوة والضعف لمعالجتها في دور معلم الرياضيات في تهيئة بيئات تعلم

تفاعلية قائمة على المعايير المهنية من وجهاة نظر المختصنين.

حدود الدراسـة:

تقتصر الدراسة الحالية على الحدود الاتية:

الحدود الموضيوعية: دور معلمي رياضيات المرحلة المتوسطة في تهيئة بيئات تعلم تفاعلية قائمة على المعايير

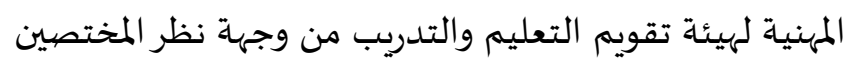

هالحدود البشرية: أعضاء هيئة المناهج وطرق تدريس الرياضيات، ومشرفي وجيه ومعلمي الرياضيات بالمرحلة

المتوسطة.

الحدود المكانية: إدارة تعليم مكة المكرمة وبعض مكاتب التعليم التابعة لها، وعلى كليات التربية بالجامعات

السعودية.

هالحدود الزمانية: وتم تطبق الدراسـة الحالية خلال الفصل الدراسي الأول (1442/1441هـ)، 
مصطلحات الدراسة Terminology of study: - معلم الرياضيات (Math teacher): يعرفه الأمين (2019، 343) المعلم مهندس عملية التعلم فهو يخطط

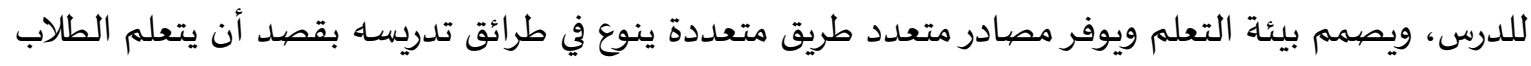

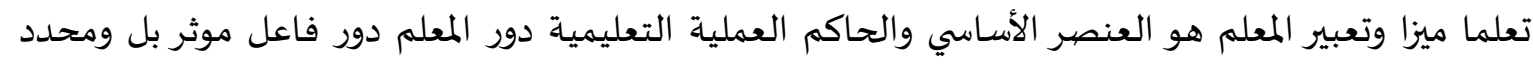
لنوعية وجودة مخرجات العملية والتعليمية. O يمكن تعريفه إجرائيا بان معلم الرياضيات وتخطيط التدريس لخلق بيئة تعليمية جاذبة وآمنة وتفاعلية

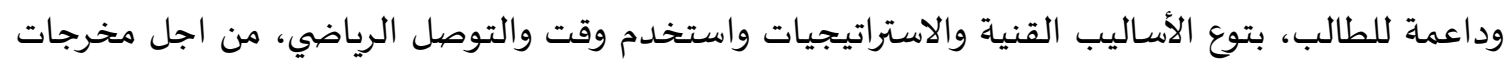

$$
\text { العملية التعليمية. }
$$

- البيئة التعليمية (تducational environment) O تعريف (حلس: 2017، ص 25) بأنه العملية التعليمية التي تهدف الأهداف المنشودة عن طريق اعتمادها على

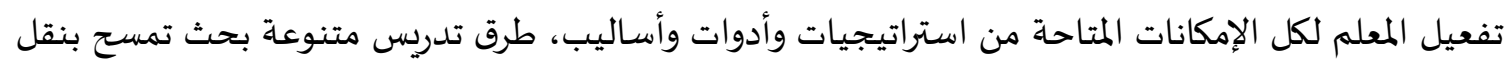

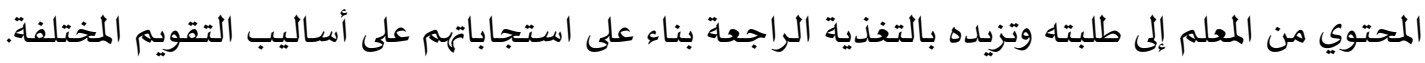

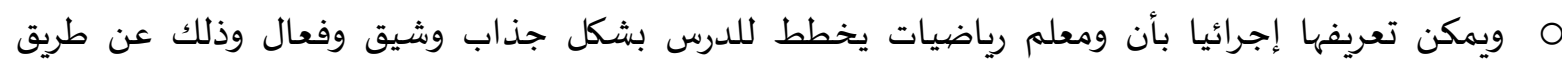

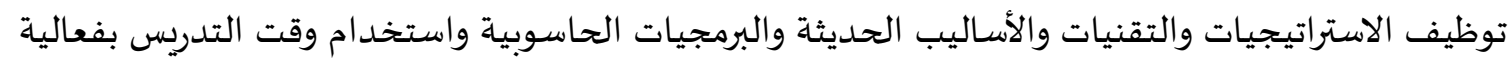

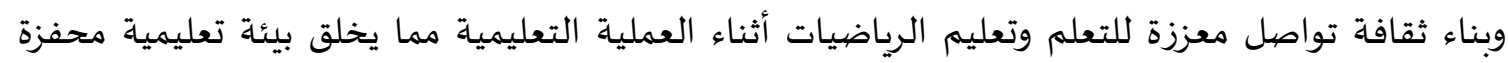

$$
\text { للابتكار والابداع. }
$$

- معايير هيئة تقويم التعليم (Standards of the Education Evaluation Authority) O هي المعايير الوظيفية الخاصة بكل مسار تعليمي، من اجل متابعة مخرجات التعليم وتقويمها وتحسينها، وتعزيز

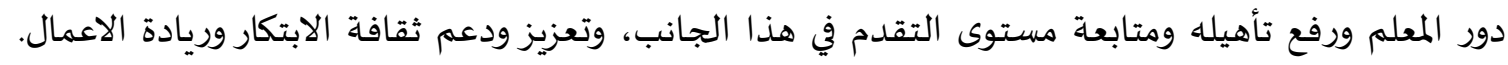

$$
\text { (هيئة تقويم التعليم والتدريب، 2017) }
$$

O وتعرفها الدراسة إجرائيا بأنها الممارسات التي يمتلكها معلم الرياضيات، لخلق بيئة تعليمية جاذبة وآمنة

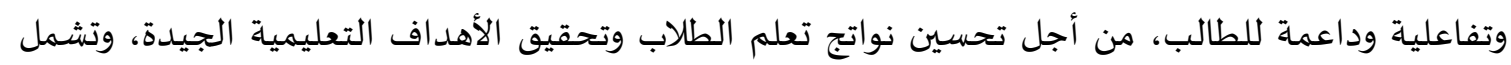

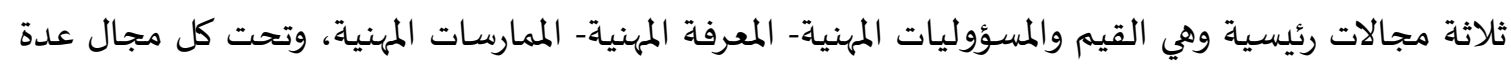

$$
\text { من المعايير. }
$$

2- منهج الدراسـة وإجراءاتها

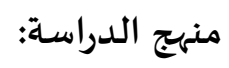

استخدم في هذه الدراسة المنهج الوصفي المستي نظرا لمناسبته لأغراض هذه الدراسة والمتمثلة في تقصي

دور معلمي رياضيات المرحلة المتوسطة في تهيئة بيئات تعلم تفاعلية قائمة على المعايير المهنية لهيئة تقويم التعليم

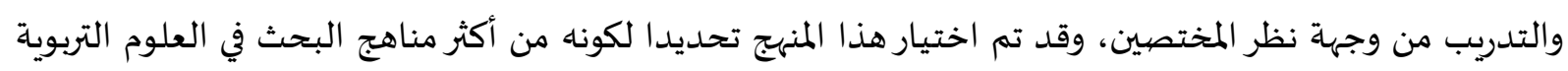

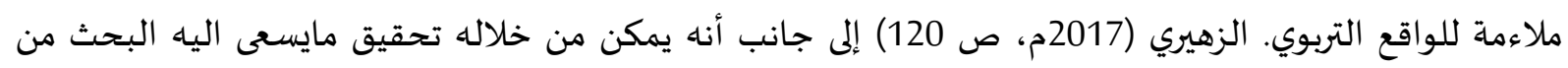

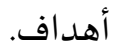


مجتمع الدراسة:

تألف مجتمع الدراسة من أعضاء هيئة المناهج وطرق تدريس الرياضيات، ومشرفي ومعلمي الرياضيات

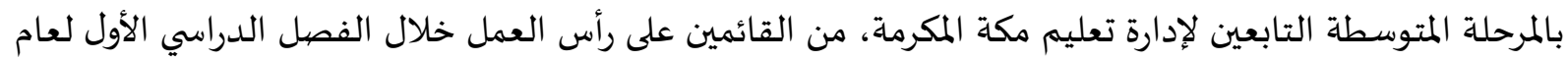

عينة الدراسـة:

تم اختيار عينة الدراسة بالطريقة العشـوائية البسيطة من أعضاء هيئة المناهج وطرق تدريس الرياضيات

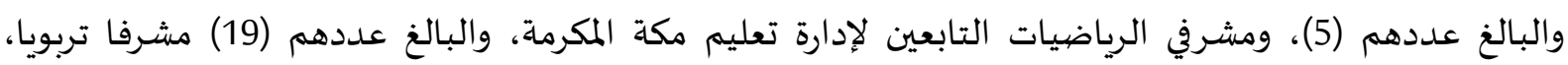
ومعلمي الرياضيات بالمرحلة المتوسطة والبالغ عددهم، (5) (106) معلماً.

أداة الدراسة وبناؤها: لتحقيق غرض الدراسة، كان من المناسب إعداد استبانة كأداة لجمع البيانات وذلك لمناسبتها لمنهج البحث والهدف العام للبحث، بتقصي دور معلمي رياضيات المرحلة المتوسطة في تهيئة بيئات تعلم تفاعلية قائمة على المعايير المهنية لهيئة تقويم التعليم والتدريب من وجهة نظر المختصين؛ هذا وقد تم بناء هذه الاستبانة وفقاً للإجراءات

1- تحديد الغرض من الاستبانة: حُدد الغرض من الاستبانة بالتعرف على دور معلمي رياضيات المرحلة المتوسطة

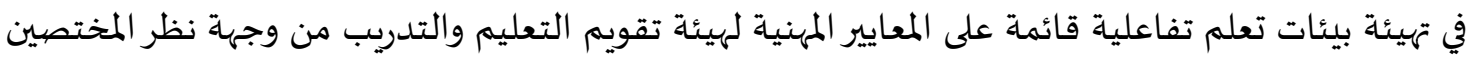

$$
\text { 2- تحديد أبعاد (محاور) الاستبانة: }
$$

تم الرجوع والاطلاع على الأدب التربوي والدراسات السابقة المتعلق ببيئة التعلم الفاعلة ودور المعلمين في تهيئة

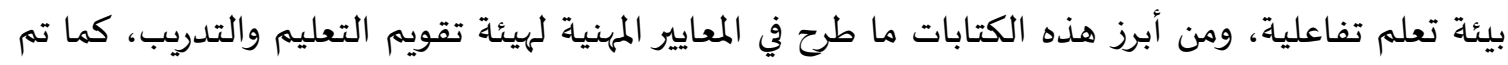

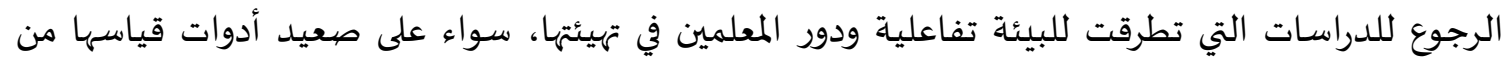

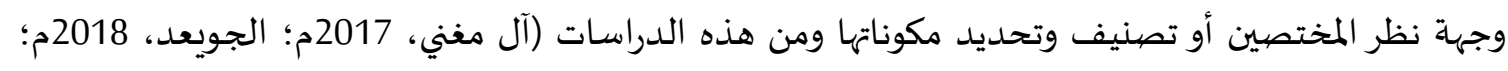

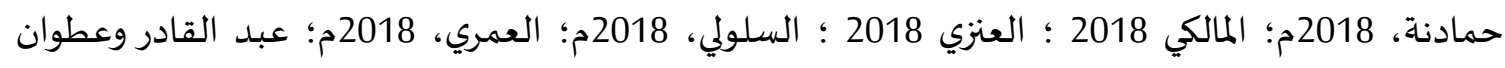

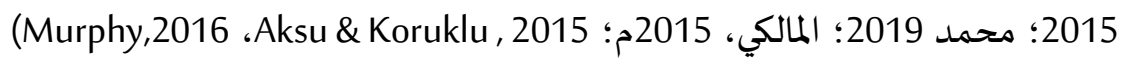
تحديد محاور الاستبانة في ضوء الاطلاع على الأدب النظري والدراسات السابقة. - - مياغة عبارات الاستبانة وتصنيفها وفقاً للمحاور. - وبعد الانتهاء من الخطوات السابقة أصبحت الاستبانة جاهزة في صورتها الأولية، حيث تكونت من قسمين

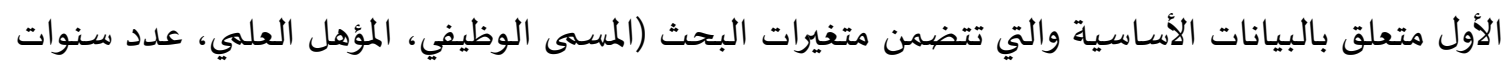

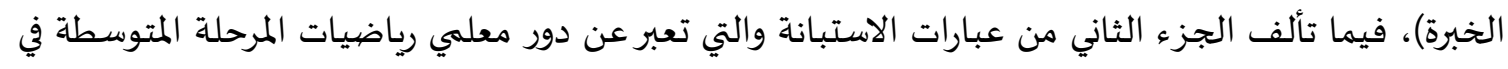

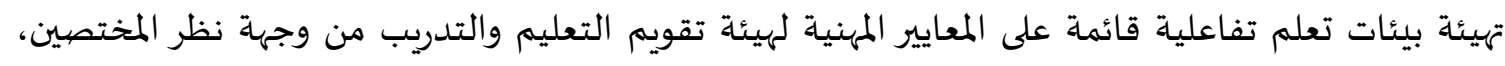

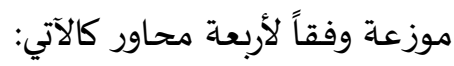
المحور الأول: استخدام التقنية الحديثة في تدريس الرياضيات ولتهات ويتضمن (6) عبارات، والمحور الثاني:

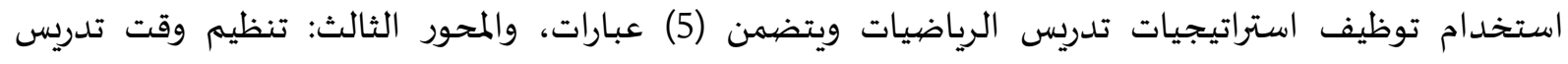

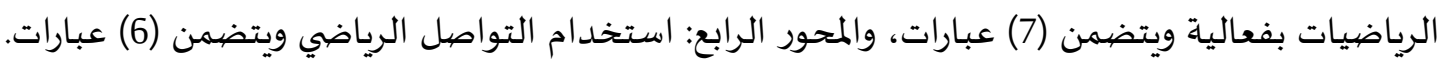




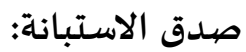

يشير الصدق (Validity) إلى قدرة الاستبانة أن تقيس ما أعدت لقياسـه، حيث يذكر الزهيري (2017) أن المقصود بصدق الأداة " أن تقيس الأداة ما وضعت من أجله، بحيث تعطي صورة كاملة وواضحة لمقدرة الفرد على الم المالى

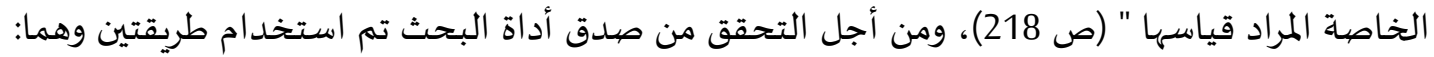

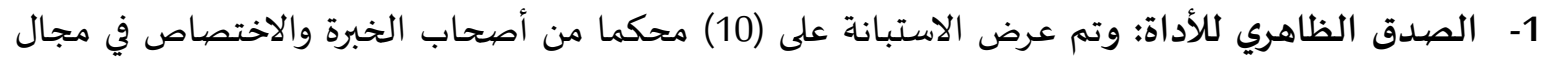
مناهج وطرق تدريس الرياضيات لتحقق من الصدق الظاهري من خلال إبداء رأيهم في الجوانب التالية: انتماء العبارة للمجال الذي صنفت ضمناه، وسلامة اللغة ودقة الصياغة، وأهمية العبارة، وحذف وتهن ونعديل

$$
\text { 2- وبدق الاتسافة ما يرونه مناسب. }
$$

طبقت الاستبانة على عينة استطلاعية قواهها (36) من خارج أفراد العينة، للتحقق من صدق الاتساق الداخلي للأداة، وذلك بحساب معامل ارتباط بيرسون بين درجة العبارة ودرجة المحور، وكذلك بين درجة المحور والدرجة الكلية للاستبانة؛ يوضح جدول (1) معاملات ارتباط بيرسون بين درجات العبارات ودرجة المحور التي صنفت ضمنها وكذلك بين درجات المحاور والدرجة الكلية للاستبانة:

\begin{tabular}{|c|c|c|c|c|c|c|c|}
\hline \multicolumn{2}{|c|}{ المحور الرابع: استخدام } & \multicolumn{2}{|c|}{ تدريس الرياضيات بفاعلية } & \multicolumn{2}{|c|}{$\begin{array}{l}\text { استحور الثيجياتي: توظيس تدريس } \\
\text { الرياضيات }\end{array}$} & \multicolumn{2}{|c|}{ المحور الأول: استخدام التقنية } \\
\hline $0.80^{* *}$ & 1 & $0.84^{* *}$ & 1 & $0.87^{* *}$ & 1 & $0.81^{* *}$ & 1 \\
\hline $0.89^{* *}$ & 2 & $0.89^{* *}$ & 2 & $0.91^{* *}$ & 2 & $0.85^{* *}$ & 2 \\
\hline $0.89^{* *}$ & 3 & $0.89^{* *}$ & 3 & $0.93^{* *}$ & 3 & $0.86^{* *}$ & 3 \\
\hline $0.87^{* *}$ & 4 & $0.88^{* *}$ & 4 & $0.93^{* *}$ & 4 & $0.85^{* *}$ & 4 \\
\hline $0.90^{* *}$ & 5 & $0.90^{* *}$ & 5 & $0.88^{* *}$ & 5 & $0.67^{* *}$ & 5 \\
\hline $0.86^{* *}$ & 6 & $0.90^{* *}$ & 6 & \multirow{3}{*}{$0.97 * *$} & \multirow{3}{*}{ الدرجة الكلية } & $0.71^{* *}$ & 6 \\
\hline \multirow[b]{2}{*}{$0.94^{* *}$} & & $0.92^{* *}$ & 7 & & & \multirow[b]{2}{*}{$0.95^{* *}$} & \multirow{2}{*}{ الدرجة الكلية } \\
\hline & الدرجة الكلية & $0.98^{* *}$ & المرجة الكلية مع المح & & & & \\
\hline
\end{tabular}

جدول (1): معاملات الارتباط لعبارات الاستبانة مع درجة المحور ودرجة المحتور مع الدرجة الكانة الكلية

وتشير النتائج في جدول (1) أن معاملات الارتباط بين درجة كل عبارة من عبارات الاستبانة ودرجة المحور

التي صنفت ضمنه قد تراوحت بين (0.93 -0.67).

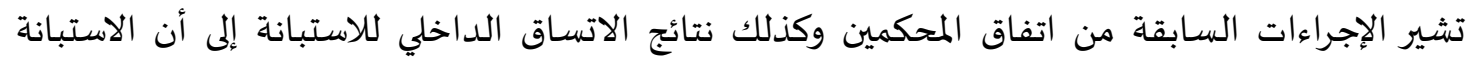
تتمتع بدرجة صدق عالية ومناسبة لأغراض البحث الحالي.

ثبات الاستبانة

ويقصد بثبات الأداة (Reliability)" اتساق النتائج المسجلة على الأداة نفسها، وبعد معامل الثبات جيدا كلما

اقترب من الواحد الصحيح، لان قيم الخطأ المعياري للقياس تصبح قريبة من الصفر، وهذا يعني أن الأداة تصبح

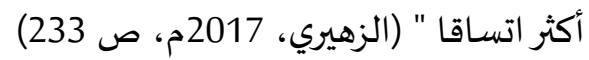

وبعد تطبيق الاستبانة على العينة الاستطلاعية السابقة الذكر، تم حساب ثبات الاستبانة بطريقة تحليل التباين باستخدام معامل ثبات ألفا كرونباخ، والجدول (3- 4) يوضيح النتائج التي حصلنا لاستها عليها: 
جدول (2): - معاملات ثبات ألفا كرونباخ

\begin{tabular}{|c|c|c|}
\hline معامل ثبات الفا كرونباخ & 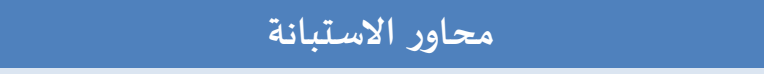 & a \\
\hline 0.87 & المحور الأول: استخدام التقنية في تدريس الرياضيات & 1 \\
\hline 0.93 & المحور الثاني: توظيف استراتيجيات تدريس الرياضيات & 2 \\
\hline 0.95 & المحور الثالث: تنظيم وقت تدريس الرياضيات بفاعلية & 3 \\
\hline 0.93 & المحور الرابع: استخدام التواصل الرياضي & \\
\hline 0.98 & الاستبانة ككل & \\
\hline
\end{tabular}

تشير معاملات الثبات في جدول (2) أن الاستبانة تتمتع بدرجة ثبات عالية، تجعل منها صالحة لأغراض

الدراسـة الحالية.

إجراءات تنفيذ الدراسة

تم اتباع الإجراءات الآتية لتنفيذ الدراسـة:

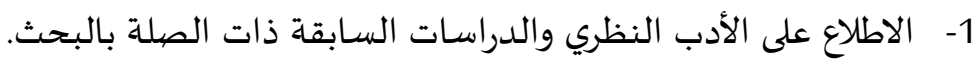

2- - تحديد مجتمع وعينة البحث وخصيائصها.

3- اختيار أداة الدراسة المناسبة وبناءها وعائة (الاستبانة).

4- التحقق من صدق وثبات الاستبانة.

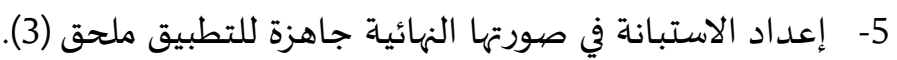

6- الحصول على خطاب تسهيل مهمة باحث ملحق (4).

7- ت توزيع الاستبانة الكترونياً على عينة الدراسة.

8- - تجميع البيانات وتبويها بعد مرور (30) يوماً من تاريخ توزيع الاستبانة.

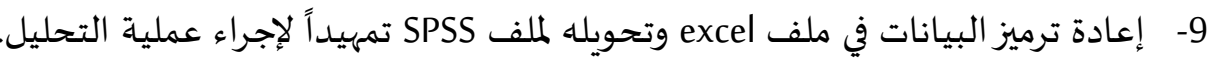

10- إجراء عملية التحليل وعرض وتنظيم النتائج والإجابة عن الأسئلة ومناقشتها.

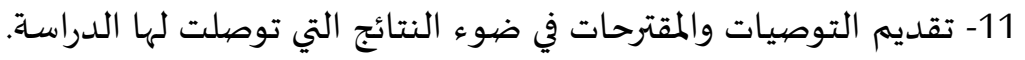

الأسـاليب الإحصيائية المستخدمة

تمت عملية التحليل والمعالجة الإحصائية باستخدام برنامج الرزم الإحصائية (SPSS) وفقاً للأساليب الآتية:

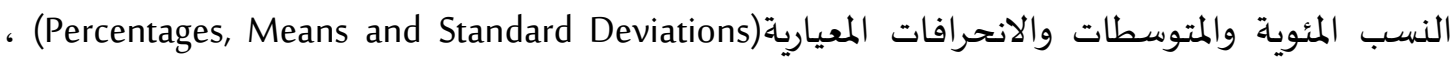

لوصف خصائص العينة وكذلك التعرف درجة استجابات العينة على عبارات الاستبانة وفقاً لمعيار ليكرت الخماسي.

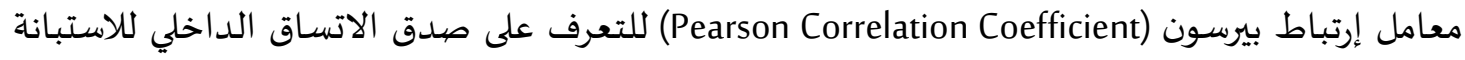

من خلال حساب معامل الارتباط بين درجة العبارة ودرجة المحور وكذلك بين درجة المحور والدرجة الكلية.

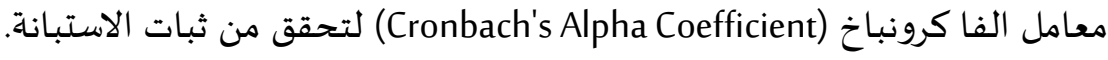

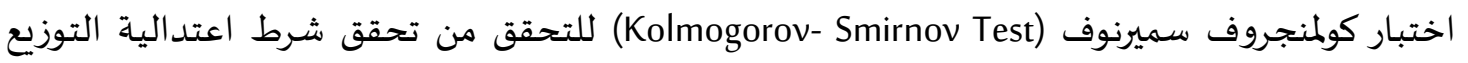

الطبيعي لدرجات المستجيبين، 
جدول (3) نتائج الاختبار للتحقق من تحقق شرط اعتدالية التوزيع الطبيعي لدرجات المستجيبين

\begin{tabular}{|c|c|c|c|}
\hline \multicolumn{2}{|c|}{ Kolmogorov-Smirnov } & درجة الحرية & \\
\hline Sig & Statistic & df & 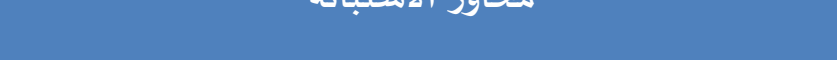 \\
\hline 0.000 & 0.190 & 130 & المحور الأول: استخدام التقنية الحديثة في تدريس الرياضيات \\
\hline 0.000 & 0.234 & 130 & المحور الثاني: توظيف استراتيجيات تدريس الرياضيات \\
\hline 0.000 & 0.235 & 130 & المحور الثالث: تنظيم وقت تدريس الرياضيات بفعالية \\
\hline 0.000 & 0.223 & 130 & المحور الرابع: استخدام التواصل الرياضي \\
\hline
\end{tabular}

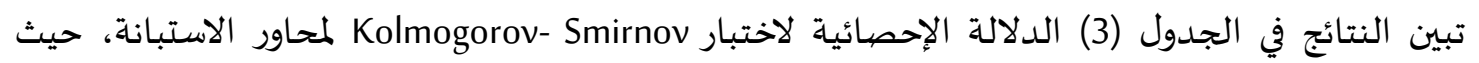

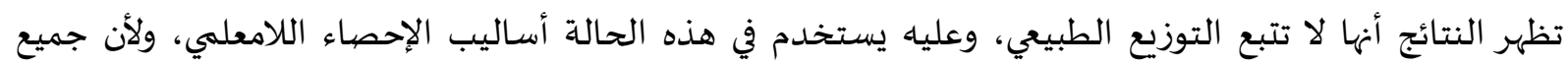

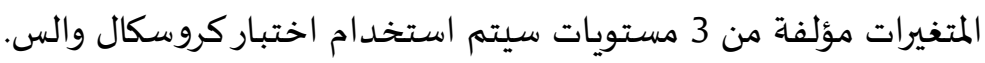

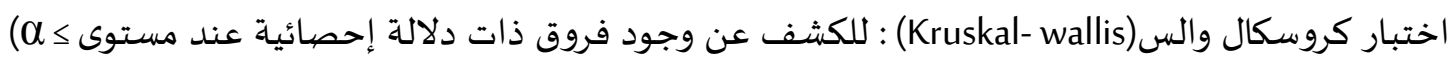

(0.05 بين متوسطات استجابات أفراد العينة عن دور معلمي رياضيات المرحلة المتوسطة في تهيئة بيئات تعلم تفاعلية

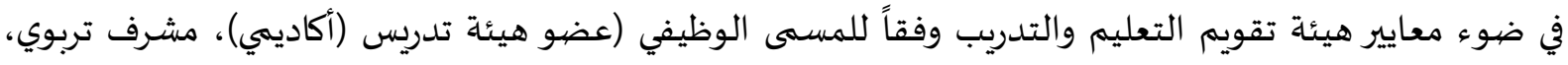
معلم رياضيات)، وكذلك وفقاً للمؤهل العلمي (دكتوراه، ماجستير، بكالوريوس)، وأيضاً وفقاً لسنوات السئ الخبرة (أقل من 5 سنوات، من 5سنوات إلى أقل من 10 سنوات، من 10 سنوات إلى أقل من 15 سنة، 15 سنة فأكثر).

\section{4- عرض نتائج الدراسة ومناقشتها.}

إجابة السؤال الأول: ما دور معلم رياضيات المرحلة المتوسطة في استخدام التقنية الحديثة في تدريس

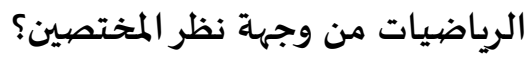

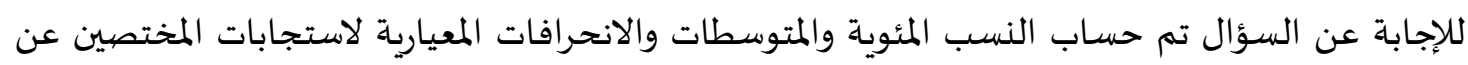
كل عبارة من عبارات محور استخدام التقنية الحديثة في تدريس الرياضيات.

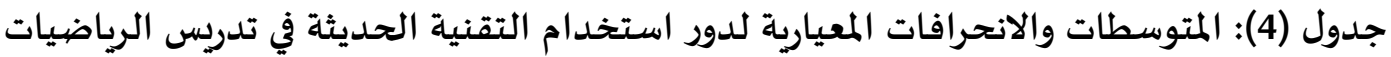

\begin{tabular}{|c|c|c|c|c|}
\hline الموافقة درجة & الالمعياري & المتوسط الحسابي & العبارة & $\hat{\imath}$ \\
\hline عالية جدا & 0.58 & 4.58 & يراعي مبادئ تعلم الطلاب ومراحلهم العمرية عند استخدام التقنيات الحديثة أثناء & 1 \\
\hline عالية & 1.1 & 4.18 & يصمم المعلم دليل إرشادي عن التقنيات الحديثة المتخصصية في تعليم وتعلم & 2 \\
\hline عالية جدا & 0.83 & 4.45 & يوضيح أبرز المشكلات التي سوف يوجهها الطلاب أثناء استخدام التقنيات الحديثة & 3 \\
\hline عالية جدا & 0.89 & 4.3 & يستخدم التطبيقات الإلكترونية في حلول المسائل الرياضية والأنشطة ذات المهارات & 4 \\
\hline عالية جدا & 0.72 & 4.55 & يوظف الفصول الافتراضية في تدريس الرياضيات أثناء زمن الحصية الدراسية لرفع التعليم وتجاوز العقبات والمشـاكل (كمشكلة فيروس كرونا (كوفيد- 19)). & 5 \\
\hline 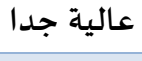 & 0.66 & 4.48 & يحث الطلاب على مصيادر مختلفة من التقنيات الحديثة لتعلم وتعليم الرياضيات. & 6 \\
\hline 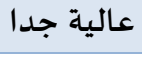 & 0.66 & 4.42 & متوسط المحور & \\
\hline
\end{tabular}


تشير النتائج في جدول (4) موافقة المختصين على عبارات دور معلم رياضيات المرحلة المتوسطة في استخدام

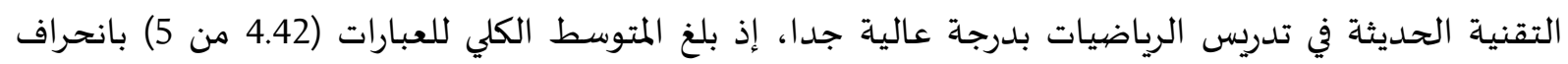

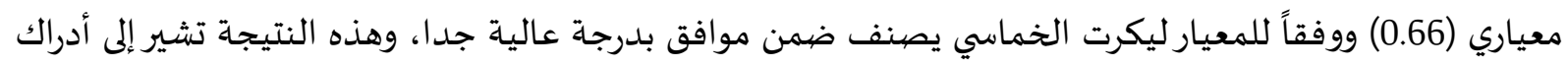

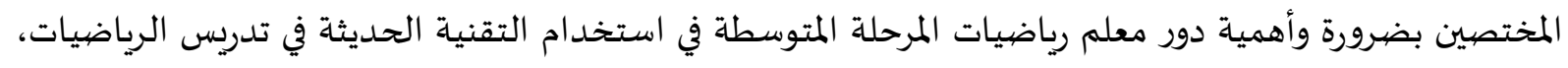

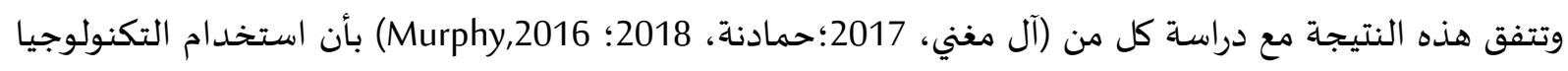

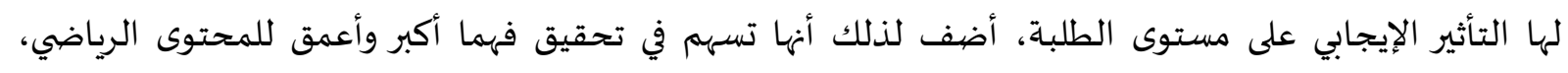

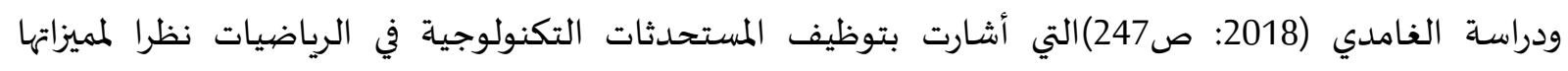

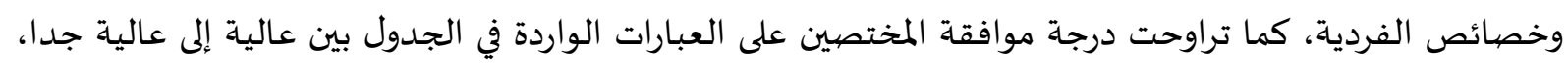

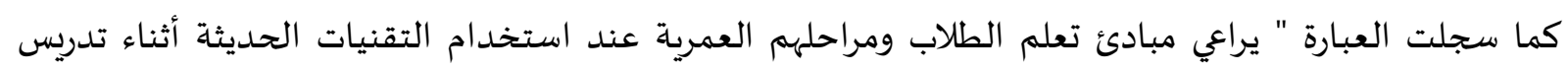

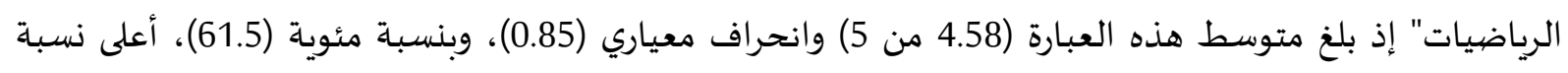

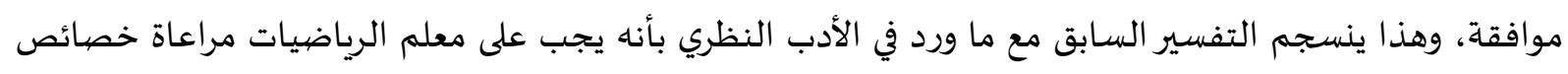

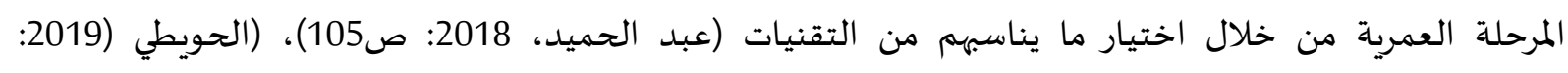

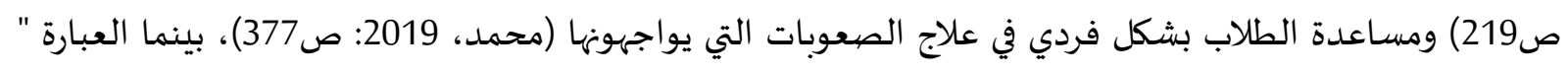
يوظف الفصول الافتراضية في تدريس الرياضيات أثناء زمن الحصة الدراسية لرفع مستوى التعليم وتجاوز العقبات

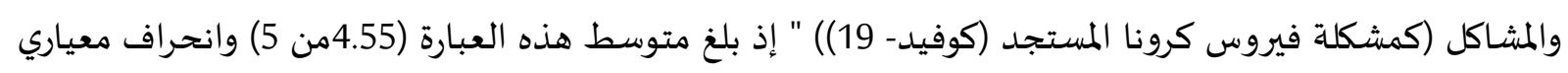

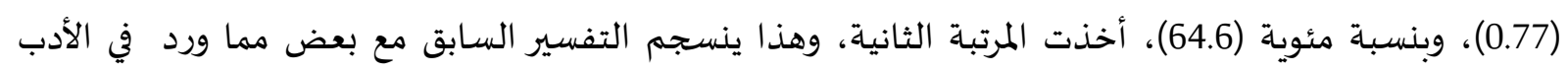

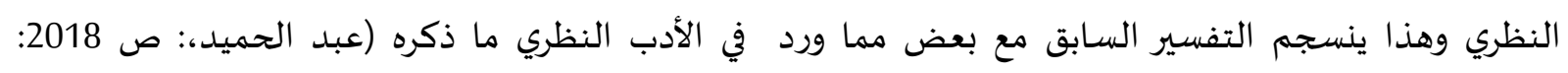

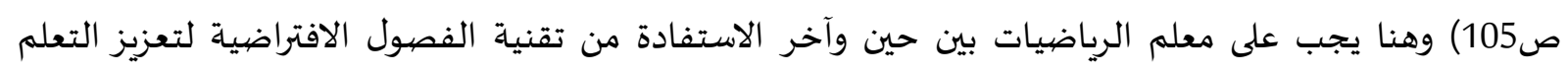

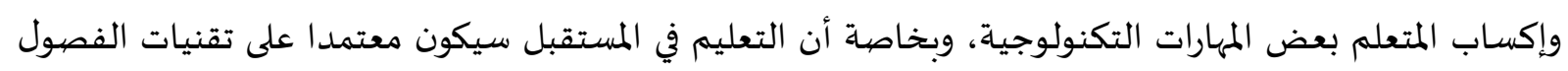

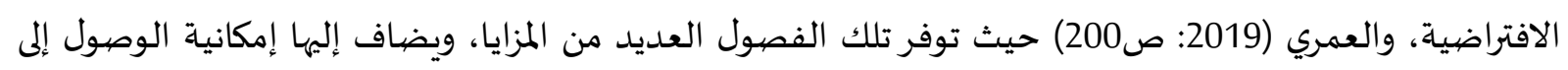

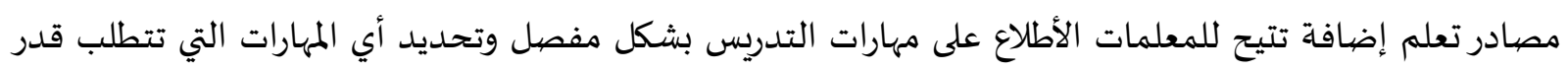

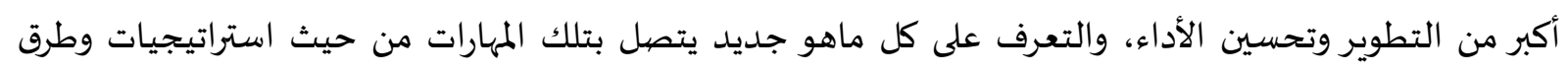

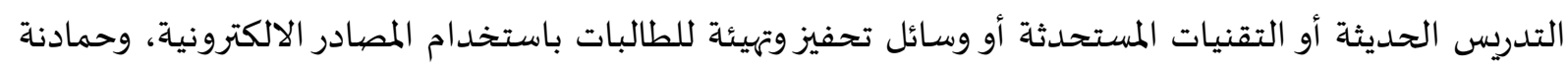
(2018: صانما 17- 18) بأن دور معلم الرياضيات لا يعد مهمته مقتصرة على المعلومات باستخدام الوسائل التقليدية

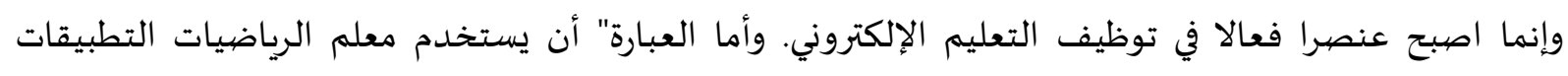

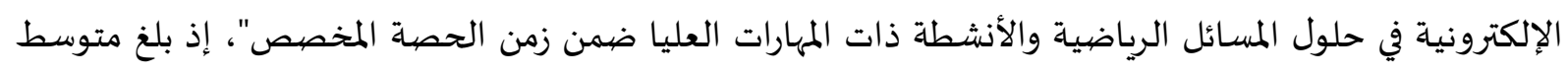

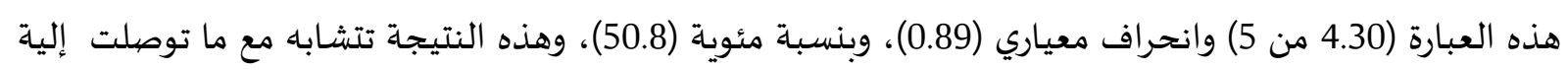

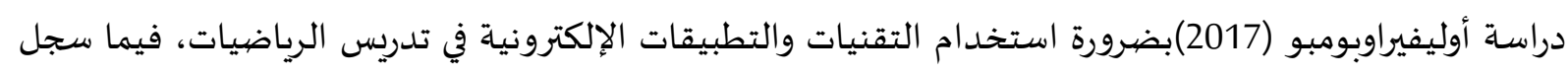
أقل نسبة مئوية وأقل متوسط للعبارة " يصمم المعلم دليل إرشادي عن التقنيات الحديثة المتخصصية في تعليم وتعلم الرياضيات "إذ بلغ متوسط هذه العبارة (4.18من 5) وانحراف معياري (1.1)، وبنسبة مئوية (52.3)، وهذا

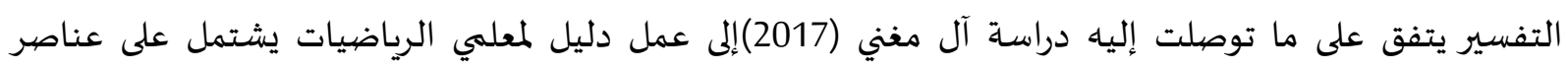
وقواعد أهمية التقنية وكيفية استخدامها لدى الطلاب في مجال الرياضيات 
إجابة السؤال الثاني: ما دور معلم رياضيات المرحلة المتوسطة في توظيف استراتيجيات تدريس الرياضيات

من وجهة نظر المختصين؟

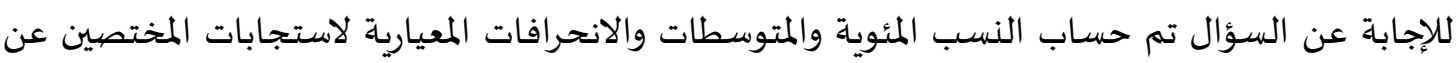

كل عبارة من عبارات محور توظيف استراتيجيات تدريس الرياضيات. جدول (5): المتوسطات والانحرافات المعيارية لبنود توظيف استراتيجيات تدريس الرئيسيات الرياضيات

\begin{tabular}{|c|c|c|c|c|}
\hline 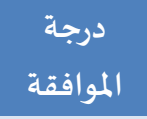 & المعياري - الافحراف & الحسبط المتوسط & العبارة & $\hat{\imath}$ \\
\hline عالية جدا & 0.72 & 4.48 & 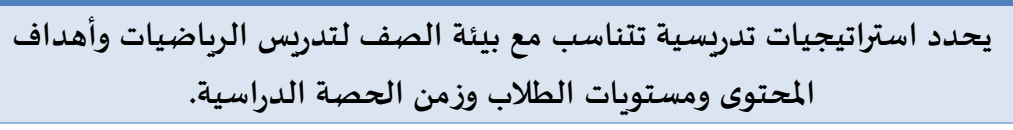 & 1 \\
\hline عالية جدا & 0.80 & 4.46 & يستخدم استراتيجيات تدريسية تدعم تعلم المعرفة الرياضية وتدفع الطلاب & 2 \\
\hline عالية جدا & 0.78 & 4.48 & ينوع الاستراتيجيات والطرق التدريسية بما يناسب أنماط تعلم الطلاب وقدراتهم & 3 \\
\hline عالية جدا & 0.79 & 4.44 & وتفاعلهم في اكتشاف التعلم بالاستراتيجيات والأساليب الحديثم ومهارات رياضية بأنفسهم داخل الحمة لنشاط الطلاب الدراسية. & 4 \\
\hline عالية جدا & 0.69 & 4.51 & 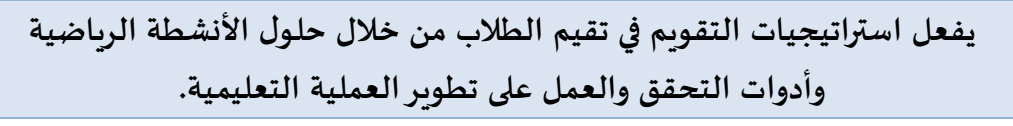 & 5 \\
\hline عالية جدا & 0.68 & 4.47 & متوسط المحور & \\
\hline
\end{tabular}

تظهر النتائج في جدول (5) موافقة المختصين على عبارات دور معلم رياضيات المرحلة المتوسطة في توظيف

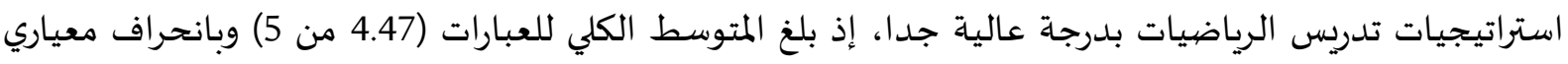

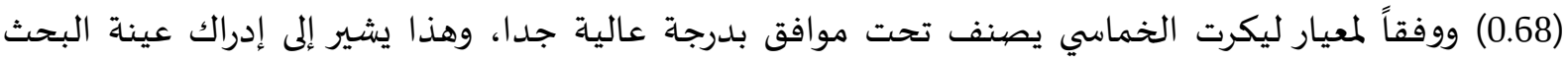
بضرورة توظيف استراتيجيات تدريس الرياضيات، وهذه النتيجة تنسجم مع ما توصلت إلية الدراسات السات السابقة كدراسة الأمين (2019) أن أسباب ضعف مستوى التحصيل في مادة الرياضيات لدى الطلبة لدية عدم التنوع في طرائق

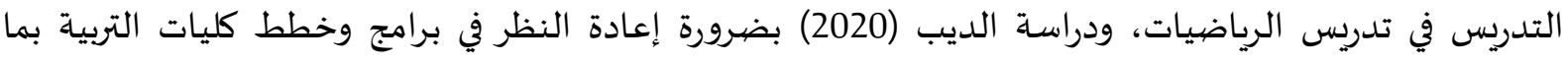

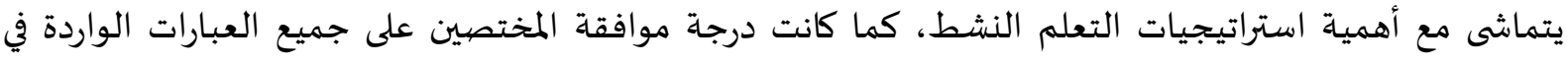

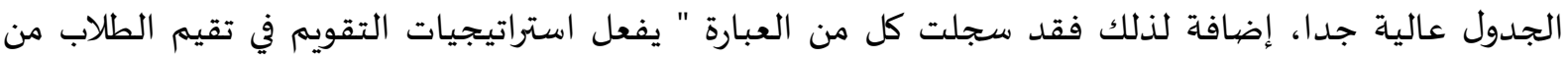

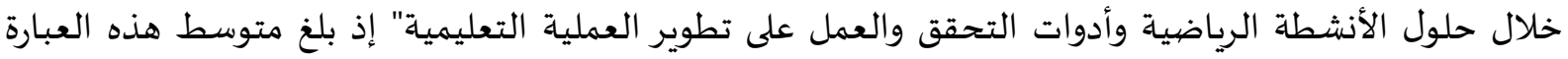

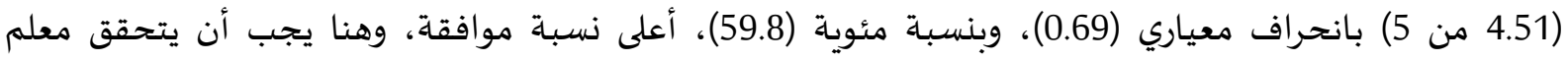

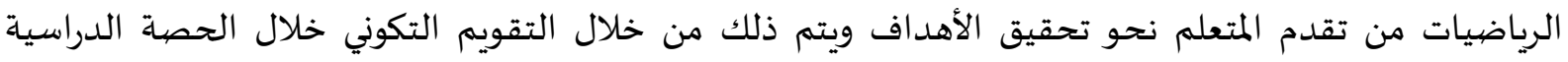
ويجب أن ينوع بين التقييم للطلبة من خلال أنشطة متنوعة وتراعي مستويات جميع المتعلمين المات الأمين، 2019:

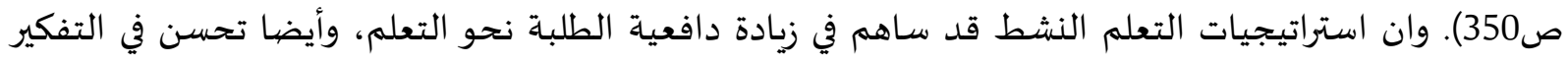
الناقد والتحصيل والاتجاه نحو الرياضيات بشكل إيجابي، (Aksu, Koruklu (2015)، بينما العبارة " يحدد

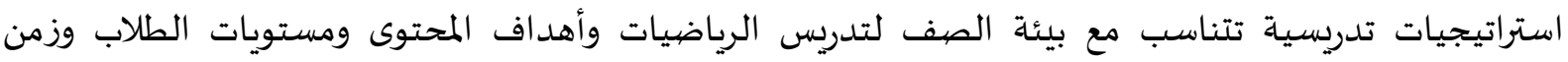
الحصة الدراسية" إذ بلغ متوسط هذه العبارة (4.48 من 5) بانحراف معياري (0.72)، ونسبة مئوية (56.2)، جاءت اتصنية

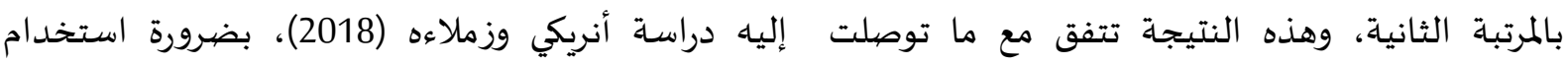

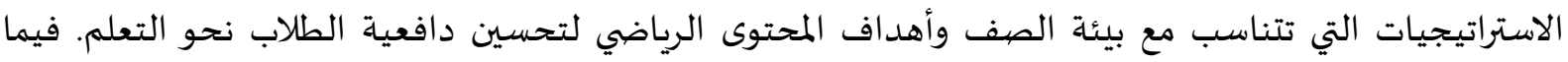

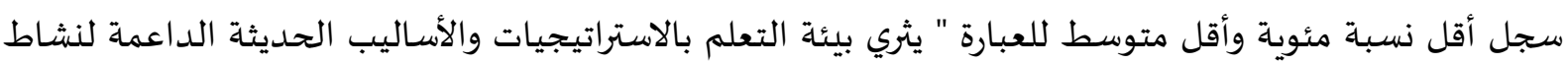


الطلاب وتفاعلهم في اكتشاف مفاهيم ومهارات رياضية بأنفسهم داخل الحجرة الدراسية" إذ بلغ متوسط هذه العبارة

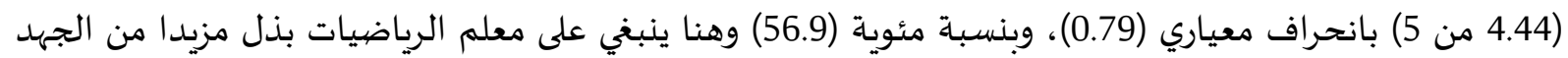

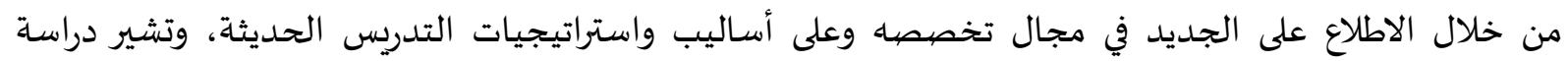

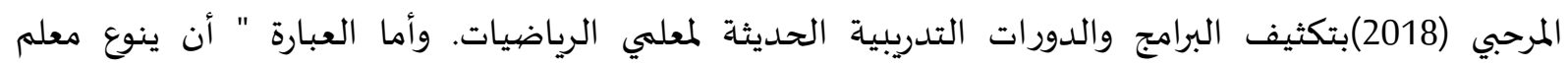

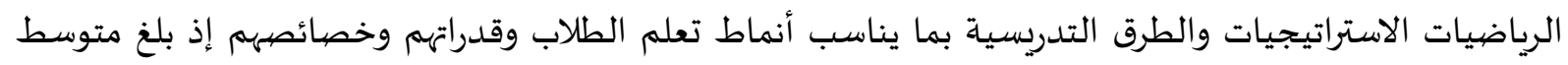

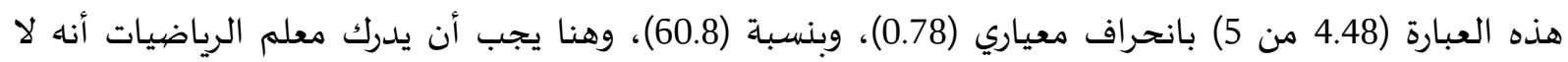

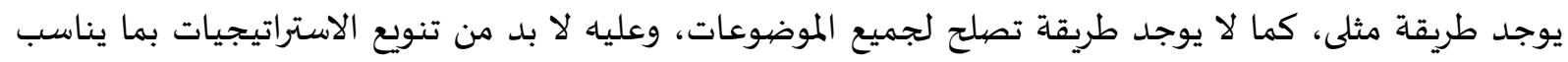

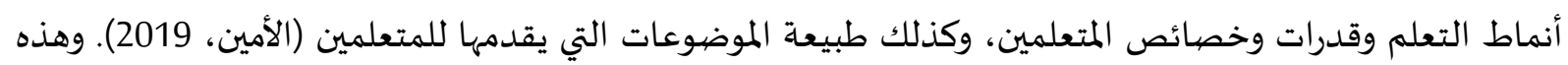
النتيجة تتشابه مع ما توصلت إليه دراسة (Aksu, Koruklu (2015) بأن هناك علاقة ارتباطية إيجابية بين الميول

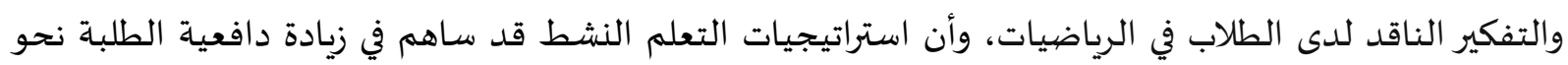
التعلم، وأيضا تحسن في التفكير الناقد والتحصيل والاتجاه نحو الرياضيات بشكل إيجابي، وذكر السر السر واخرون،

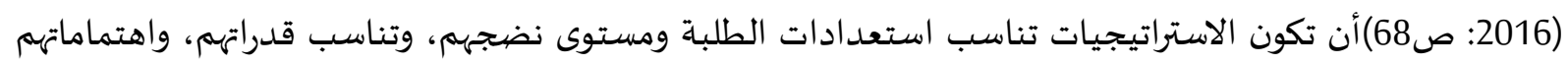

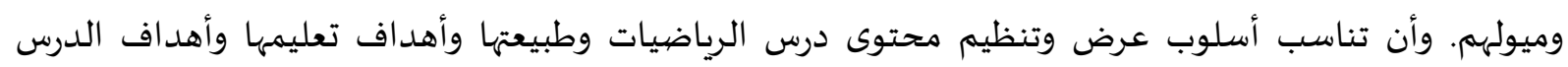
المقصود، وان تحقق مشاركة واسعة لجميع الطلبة بمختلف مستوياتهم.

إجابة السؤال الثالث: ما دور معلم رياضيات المرحلة المتوسطة في تنظيم وقت تدريس الرياضيات بفعالية من وجهة نظر المختصين؟ للإجابة عن السؤال تم حساب النسب المئئية والمتوسطات والانحرافات المعيارية لاستجابات المات المختصين عن كل عبارة من عبارات محور تنظيم وقت تدريس الرياضيات بفعالية، جدول (6) المتوسطات والانحرافات المعيارية لإجابات العينة على عبارات دور معلم رياضيات إتيات المرحلة المتوسطة في تنظيم وقت تدريس الرياضيات بفعالية

\begin{tabular}{|c|c|c|c|c|}
\hline 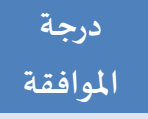 & 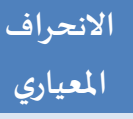 & | الحسبابي | المتوسط & 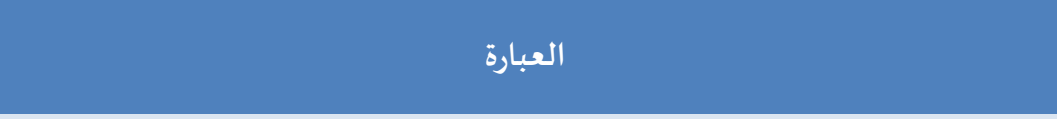 & $\hat{\imath}$ \\
\hline عالية جدا & 0.69 & 4.57 & يعد خطة فصلية ويومية لتدريس الرياضيات تتناسب مع زمن الحصية الدراسية. & 1 \\
\hline عالية جدا & 0.77 & 4.53 & يحدد الوقت اللازم لتنفيذ كل خطوة من خطوات تدريس الرياضيات الأربع (التركيز- & 2 \\
\hline عالية جدا & 0.73 & 4.52 & يتمكن من إدارة الوقت لتنفيذ الاستراتيجيات والتطبيقات الإلكترونية المناسبة & 3 \\
\hline عالية جدا & 1.04 & 4.22 & يجد وقت كافي لتقديم خطط علاجية للطلاب في المستوى دون المتوسط بشكل متزامن & 4 \\
\hline عالية جدا & 0.82 & 4.42 & 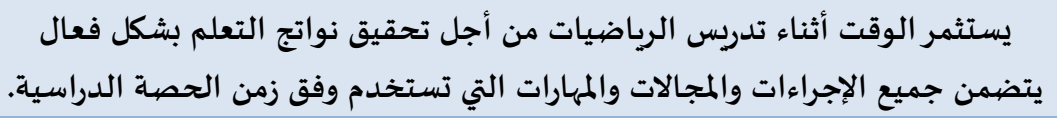 & 5 \\
\hline عالية جدا & 0.93 & 4.30 & يتطرق للأنشطة ذات مهارات التفكير العليا والمسائل اللفظية مع زمن الحصة & 6 \\
\hline عالية جدا & 0.75 & 4.47 & 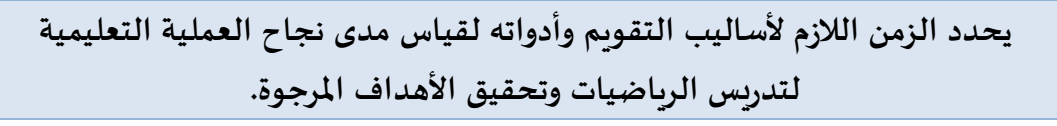 & 7 \\
\hline عالية جدا & 0.73 & 4.43 & متوسط المحور & \\
\hline
\end{tabular}


توضح النتائج في جدول (6) موافقة المختصين بدرجة عالية جدا على عبارات دور معلم رياضيات المرحلة

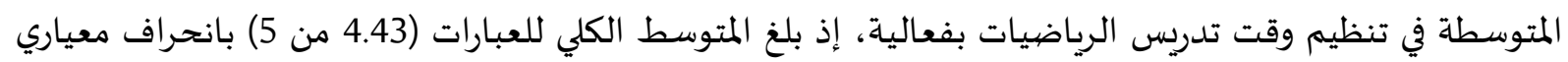

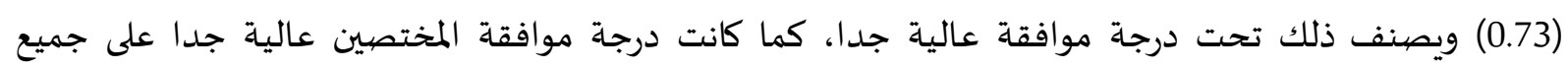
عبارات تنظيم وقت تدريس الرياضيات بفعالية، وهذه النتيجة تتفق مع العديد من الدراسات السابقة كدراسة دواسة

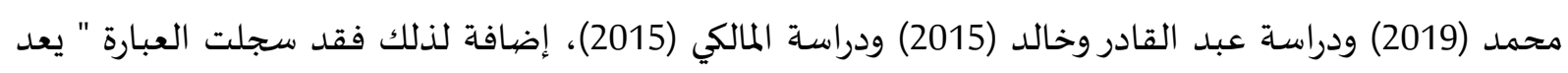

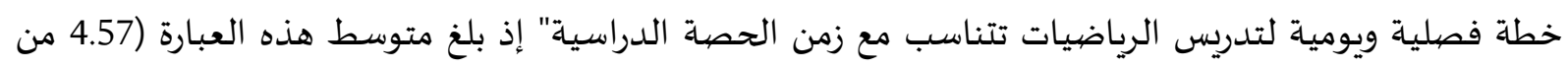

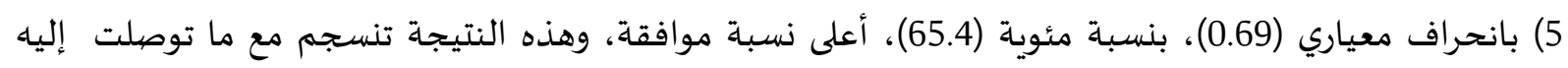

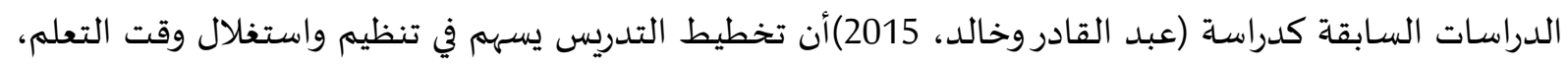

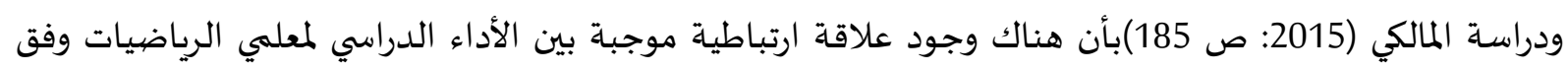

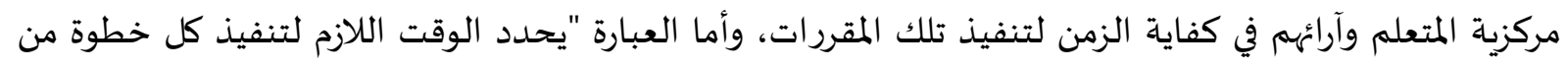

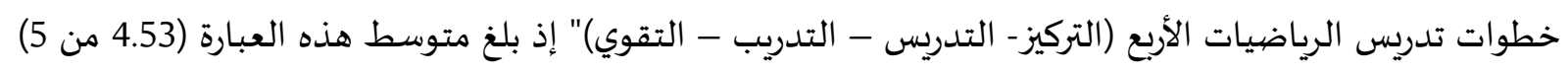

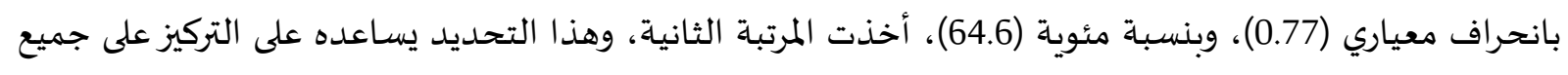

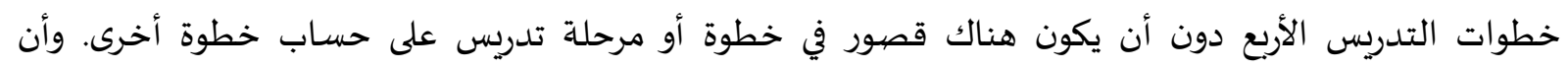
تخطيط الدروس اليومية عملية هدفها الأسساسي هو رسم صورة واضحة المان لما يمكن أن يقوم به المعلم هو طلابه أثناء

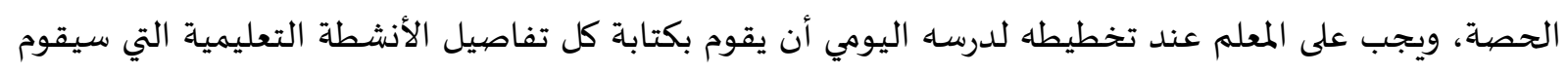

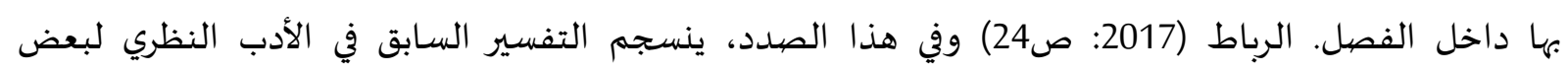

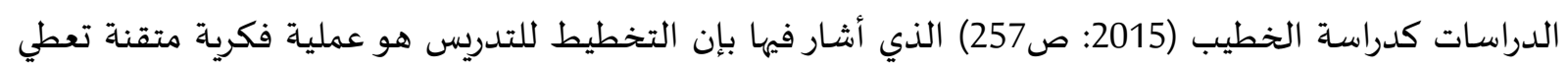

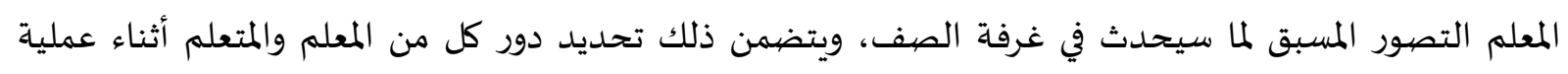

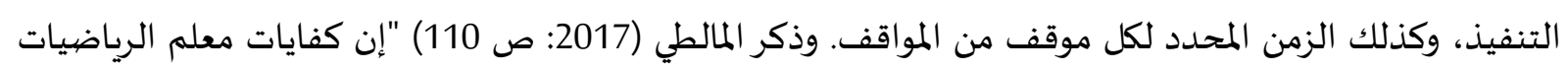

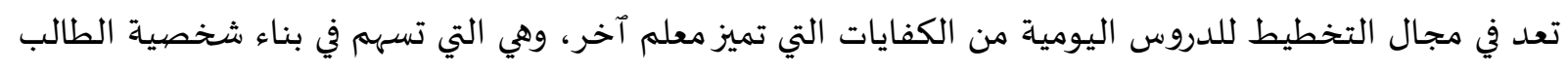

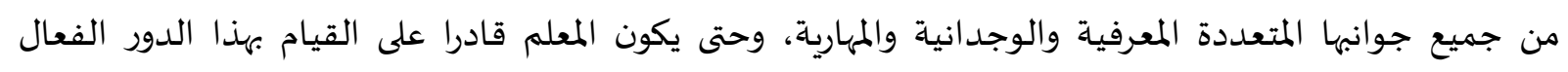

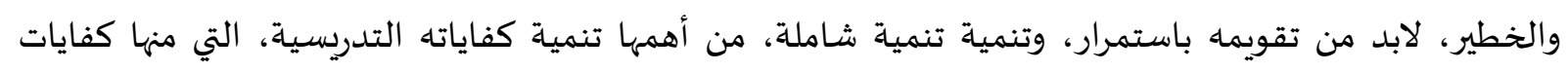

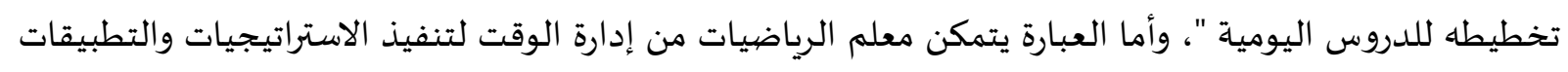

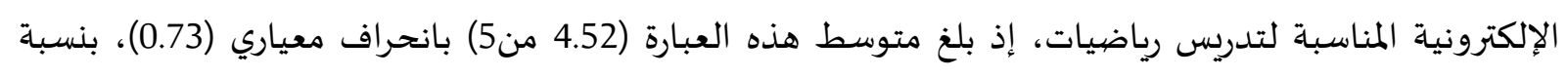

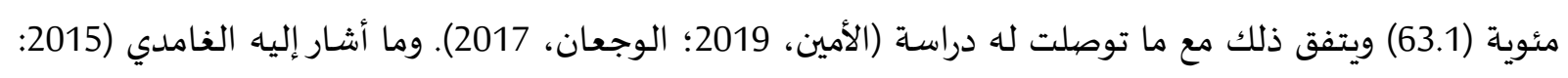

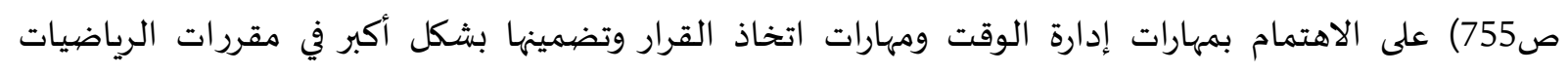

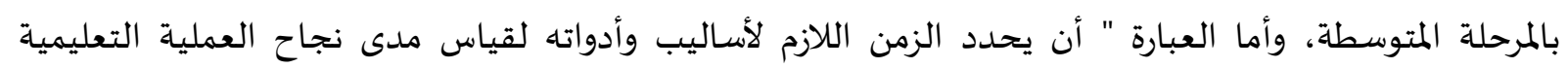

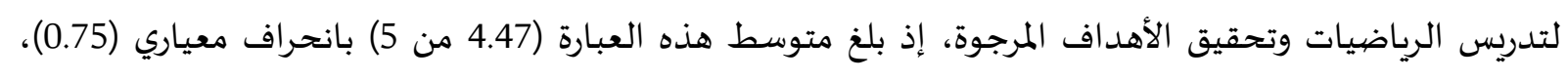

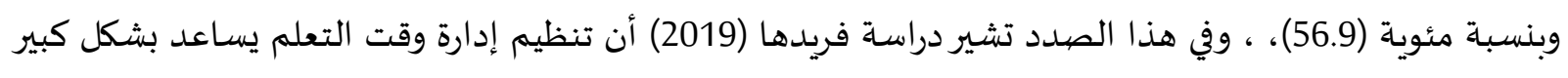

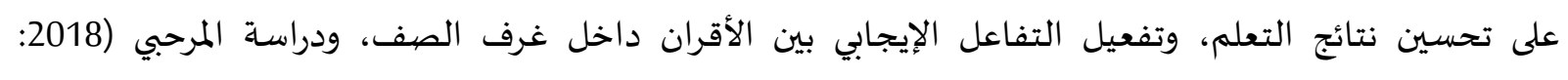

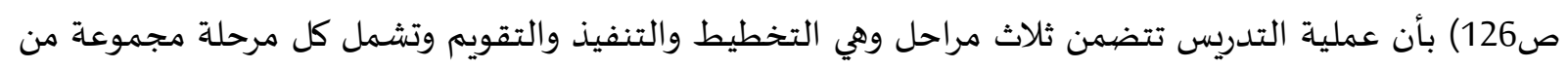

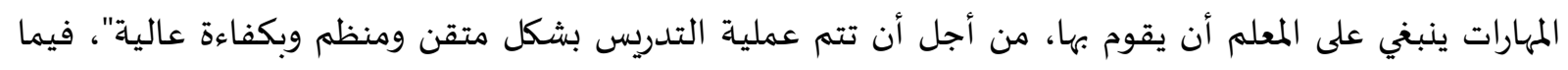

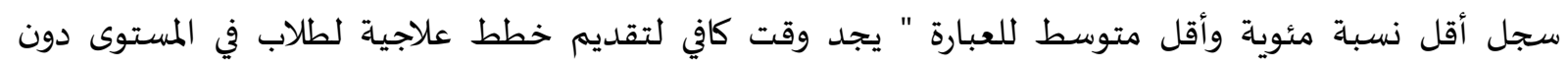

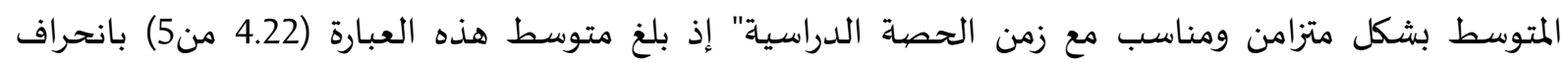

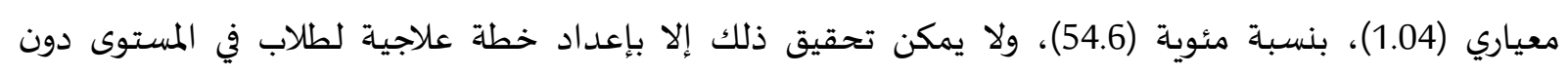


المتوسط باستثمار وتنظيم وقت الحصة الدراسية، وينسجم هذا التفسير مع ما توصلت لله دراسة فريدها (2019)أن

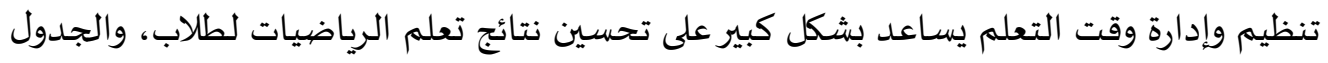

إجابة السؤال الرابع: ما دور معلم رياضيات المرحلة المتوسطة في استخدام التواصل الرياضي من وجهة نظر

المختصين؟

للإجابة عن السؤال تم حساب النسب المئوية والمتوسطات والانحرافات المعيارية لاستجابات المختصين عن

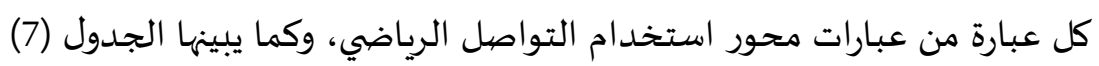

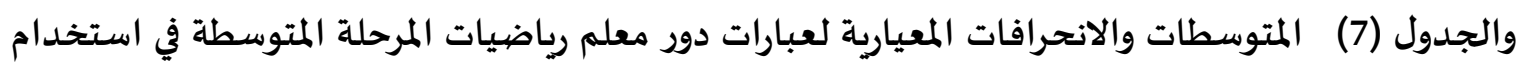

التواصل الرياضي.

\begin{tabular}{|c|c|c|c|c|}
\hline دورجة & الانمحاف المياري & المتوسـا & العبارة & $\hat{\imath}$ \\
\hline عالية جدا & 0.63 & 4.58 & 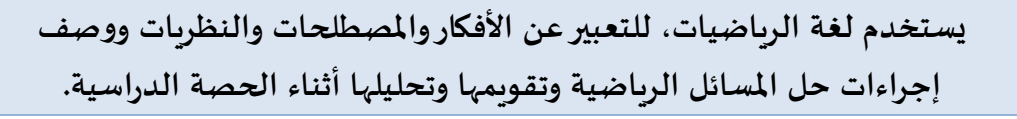 & 1 \\
\hline عالية جدا & 0.64 & 4.51 & ينوع المسائل الرياضية والأساليب الداعمة للممارسة التواصل الرياضي ضمن زمن & 2 \\
\hline عالية جدا & 0.69 & 4.50 & يعد خطة لإدارة الصف أثناء المناقشات الرياضية والتفاعلات الصفية لتعزيز التعلم وتطوير العلاقات الإيجابية القائمة على الاحترام والعدالة. & 3 \\
\hline عالية جدا & 0.69 & 4.49 & 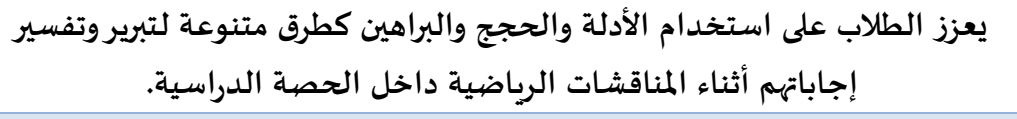 & 4 \\
\hline عالية جدا & 0.78 & 4.44 & يستخدم استراتيجية الكتابة من أجل التعلم في تعليم الرياضيات لتنظيم الأفكار & 5 \\
\hline عالية جدا & 0.65 & 4.50 & 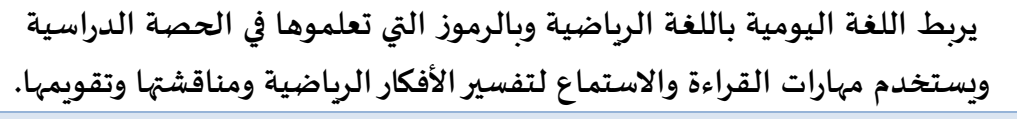 & 6 \\
\hline عالية جدا & 0.59 & 4.50 & متوسط المحور & \\
\hline
\end{tabular}

تشير النتائج في جدول (7) موافقة المختصين بدرجة عالية جدا على عبارات دور معلم رياضيات المرحلة

المتوسطة في استخدام التواصل الرياضي، إذ بلغ المتوسط الكلي للعبارات (4.50 من 5) بانحراف معياري (0.59) ووفقاً لمعيار ليكرت الخماسي يصنف ذلك تحت درجة موافقة عالية جدا، وهذا يشير إلى إدراك عينة البحث بأهمية

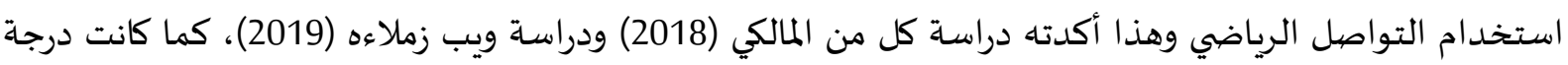

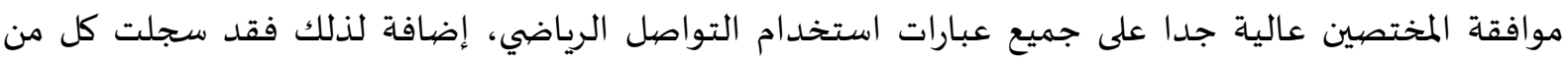

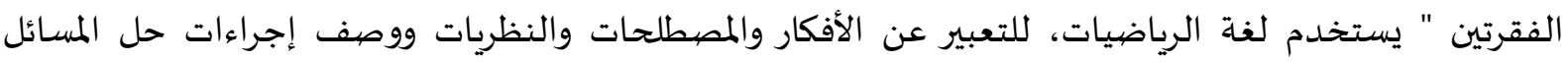

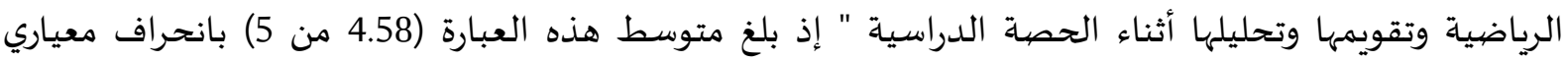

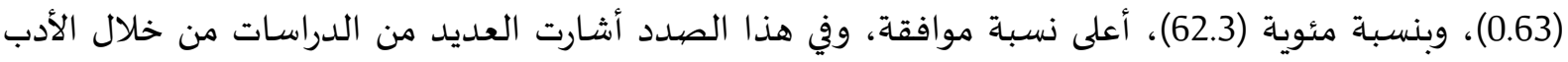

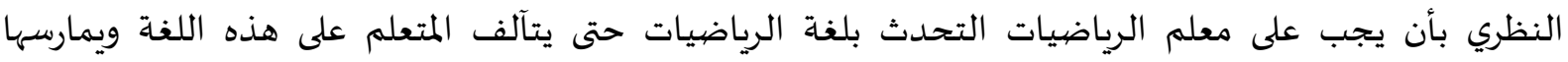

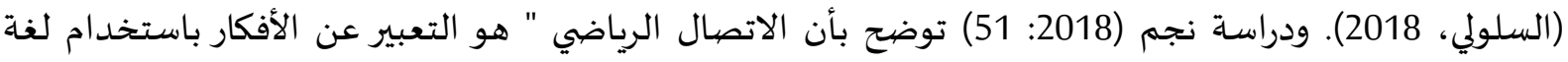

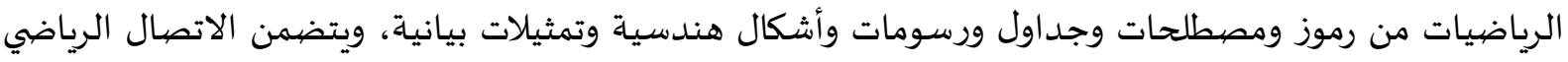

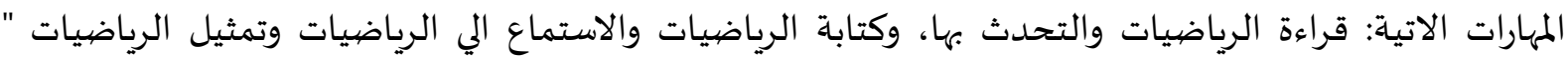
ودراسة القحطاني (2018: ص 102) تجد أن أهمية التواصل الرياضي تساعد على تحسين وتعزيز الفهم للرياضيات 
لدى الطلبة وتزيد من قدرة الطلبة نحو التعليم، والتفكير في أنشطة التعلم وتأملها، وتدعم الطلاب لتعلمهه وربط

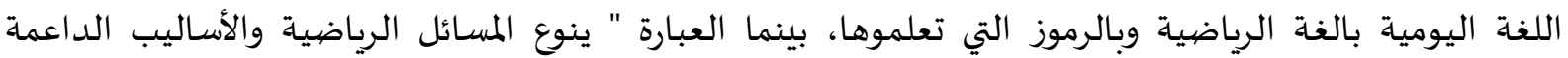

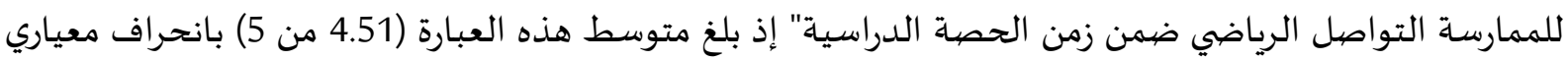

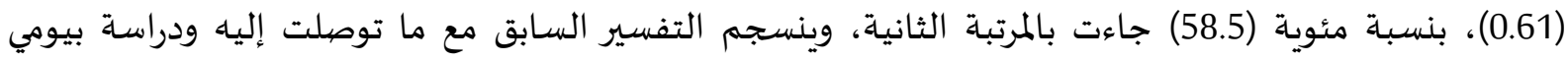

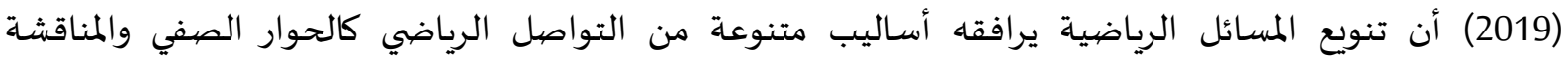
الرياضية، ودراسة الرحيلي (2018: صاضيان). "أن تنوع الأنشطة التعليمية يسهم في تعزيز ودعم مهارات التواصل

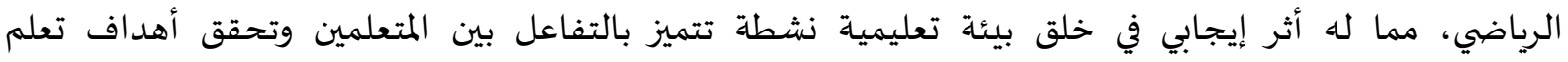

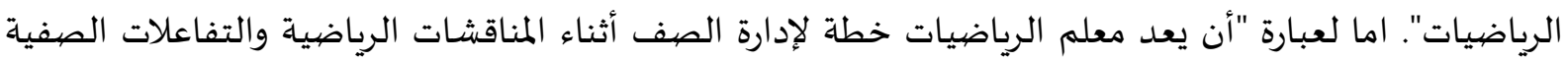

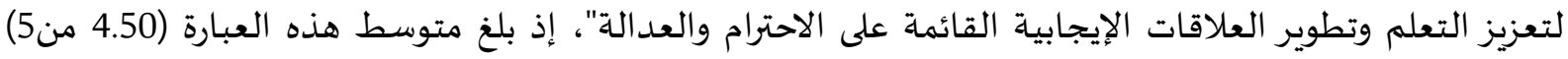

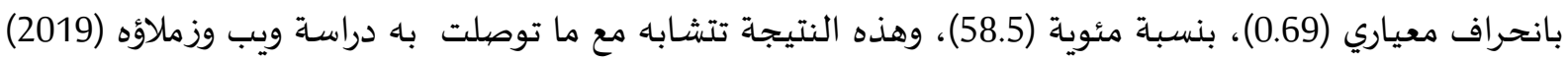

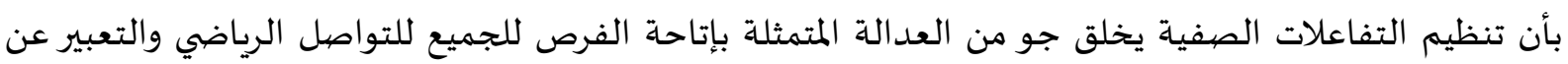

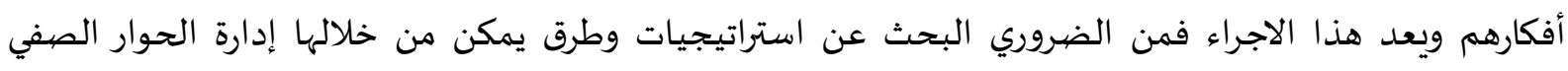

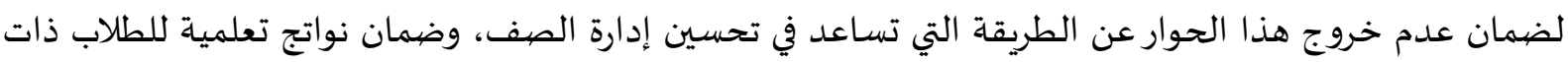

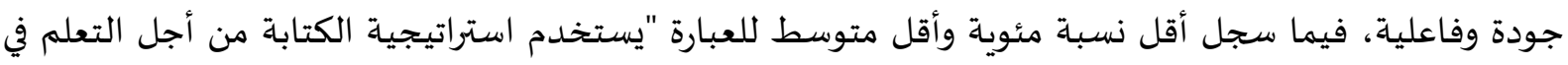

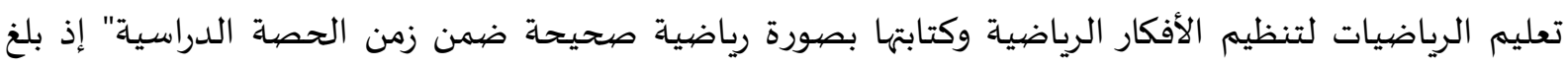

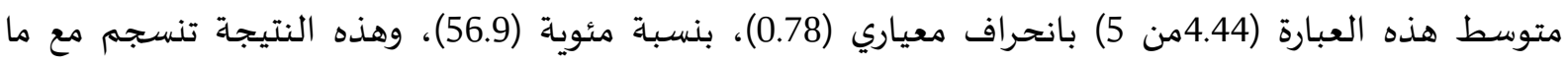
توصلت إليه دراسة السلولي (2018)بأن هناك علاقة ارتباطية بين مهارات التوصل الرياضي الكتابي والتحصيل الدراسي ذات دلالة متوسطة.

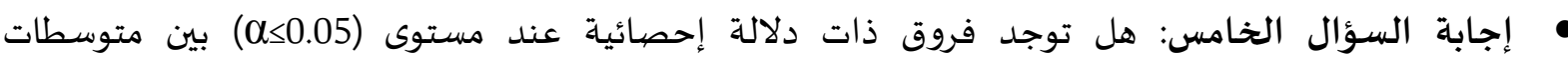

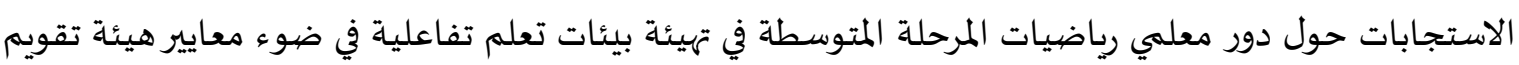

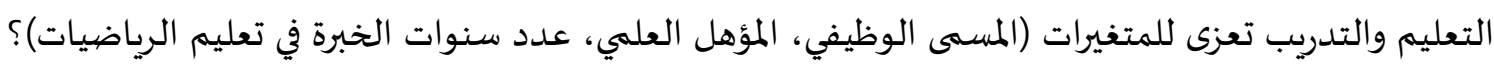

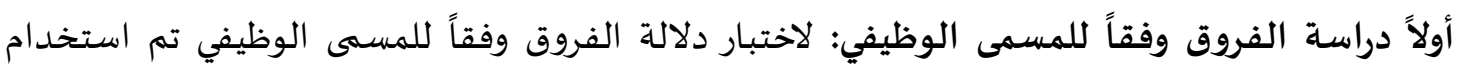
اختبار Kruskal- wallis نظرا لأن المسمى الوظيفي يتألف من ثلاثة مستويات (عضو هيئة تدريس (أكاديمي)، مشرف

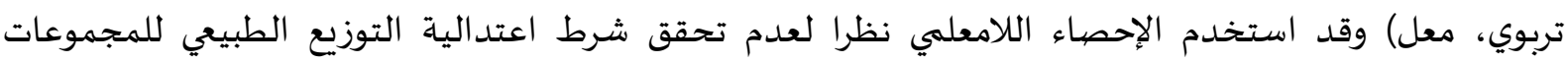

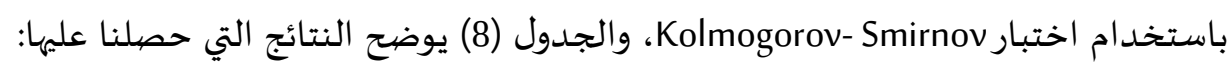
جدول (8): اختبار Kruskal- wallis للتعرف على دلالة الفروق وفقاً للمسمى الوظيفي

\begin{tabular}{|c|c|c|c|c|c|}
\hline Sig & درجة الحربة & قيمة مريع كاي & متوسط الرتب & $\mathbf{N}$ & سنوات التدريس \\
\hline \multicolumn{6}{|c|}{ المحور الأول: استخدام التقنية الحديثة في تدريس الرياضيات } \\
\hline \multirow{3}{*}{0.052} & \multirow{3}{*}{2} & \multirow{3}{*}{5.93} & 68.59 & 106 & معلم مع \\
\hline & & & 46.63 & 19 & مشرف تربوي \\
\hline & & & 71.7 & 5 & عضو هيئة تدريس (أكاديمي) \\
\hline \multicolumn{6}{|c|}{ المحور الثاني: توظيف استراتيجيات تدريس الرياضيات } \\
\hline \multirow{3}{*}{0.024} & \multirow{3}{*}{2} & \multirow{3}{*}{7.434} & 68.57 & 106 & معلم \\
\hline & & & 45.24 & 19 & مشرف تربوي \\
\hline & & & 77.5 & 5 & عضو هيئة تدريس (أكاديمي) \\
\hline
\end{tabular}


المجلة العربية للعلوم ونشر الأبحاث ـ مجلة العلوم التريوية والنفسية ـ المجلد السادس ـ العدد الخامس ـ يناير 2022م

\begin{tabular}{|c|c|c|c|c|c|}
\hline Sig & 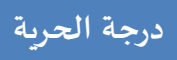 & قيمة مربع كاي & متوسط الرتب & $\mathbf{N}$ & سنوات التدريس \\
\hline \multicolumn{6}{|c|}{ المحور الثالث: تنظيم وقت تدريس الرياضيات بفاعلية } \\
\hline \multirow{3}{*}{0.072} & \multirow{3}{*}{2} & \multirow{3}{*}{5.275} & 68.39 & 106 & 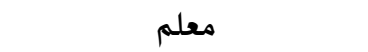 \\
\hline & & & 48.08 & 19 & مشرف تربوي \\
\hline & & & 70.4 & 5 & عضيو هيئة تدريس (أكاديمي) \\
\hline \multicolumn{6}{|c|}{ المحور الرابع: استخدام التواصل الرياضي } \\
\hline \multirow{3}{*}{0.034} & \multirow{3}{*}{2} & \multirow{3}{*}{6.749} & 68.34 & 106 & 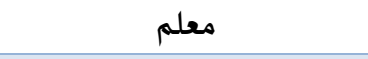 \\
\hline & & & 46.18 & 19 & مشرف تربوي \\
\hline & & & 78.7 & 5 & عضيو هيئة تدريس (أكاديمي) \\
\hline \multicolumn{6}{|c|}{ 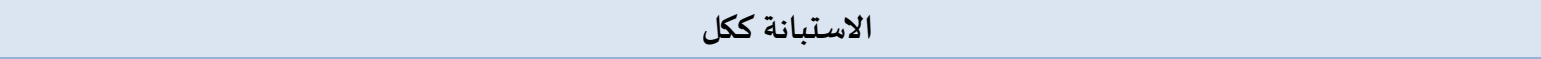 } \\
\hline \multirow{3}{*}{0.047} & \multirow{3}{*}{2} & \multirow{3}{*}{6.126} & 68.87 & 106 & 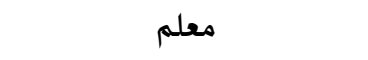 \\
\hline & & & 46.08 & 19 & مشرف تربوي \\
\hline & & & 67.9 & 5 & عضيو هيئة تدريس (أكاديمي) \\
\hline
\end{tabular}

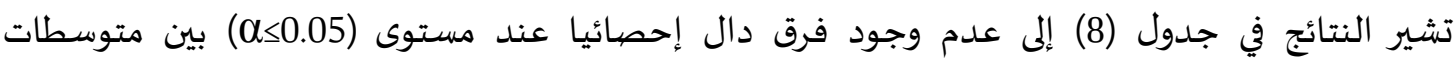
استجابات المختصين وفقاً للمسهى الوظيفي (معلم، مشرف تربوي، عضو هيئة تدريس) حول دور معلمي رياضيات المرحلة المتوسطة في المحور الأول (استخدام التقنية في تدريس الرياضيات) والمحور الثالث (تنظيم وقت تدريس

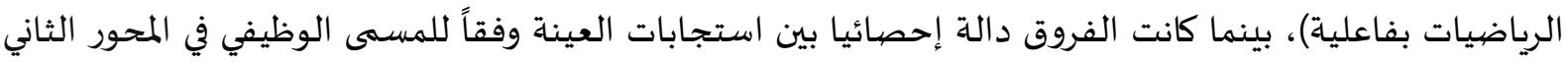

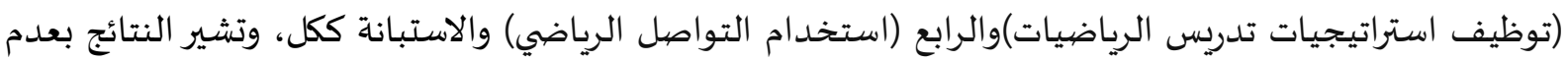

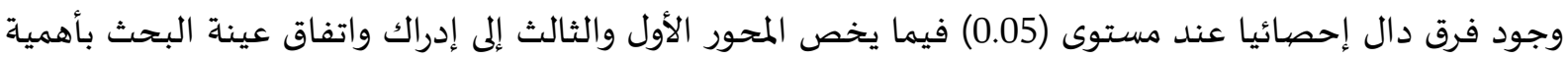

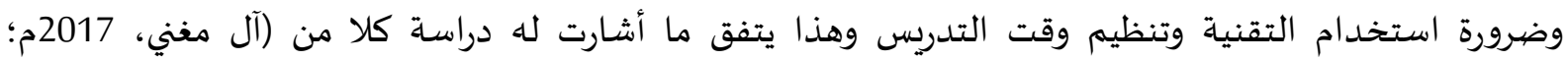

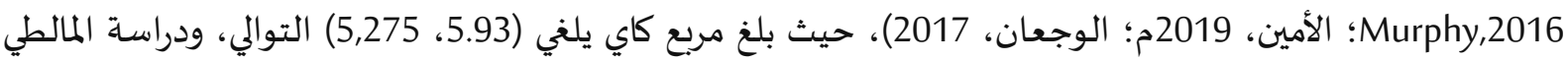

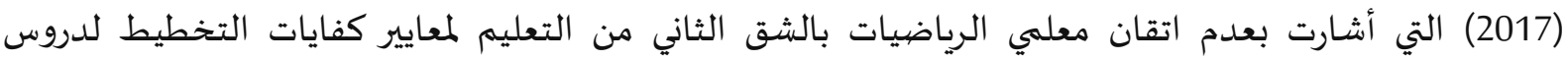

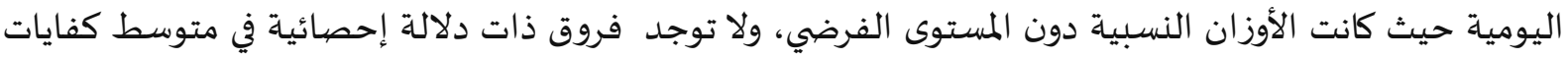

التخطيط اليومية.

أما فيما يخص المحور الثاني (توظيف استراتيجيات تدريس الرياضيات)والرابع (استخدام التواصل الرياضي) والتي وجدت فروق بين متوسطات الاستجابة وفقاً للمسمى فقد يرجع السبب في ذلك إلى إلى تباين الخلفيات

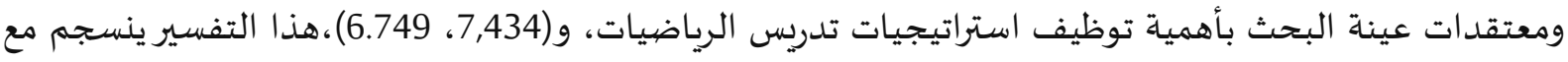
دراسة العتيبي (2019) أن توظيف المعلمين لاستراتيجيات التعليم الإلكتروني في تدريس الرياضيات بشكل عام كان

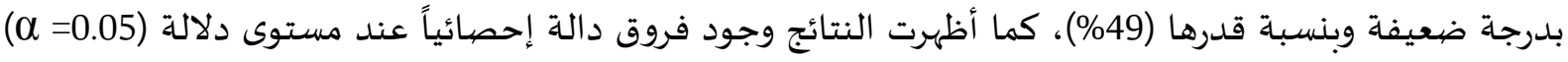

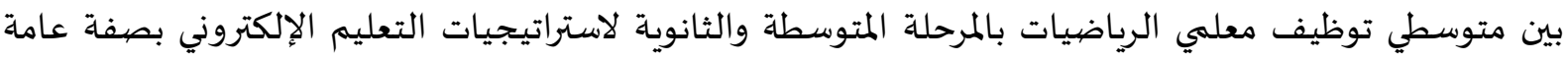

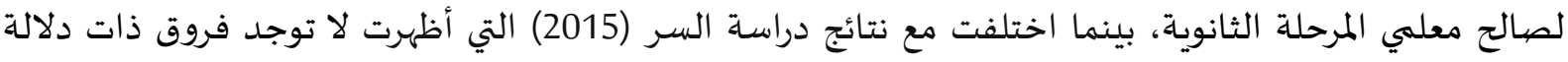

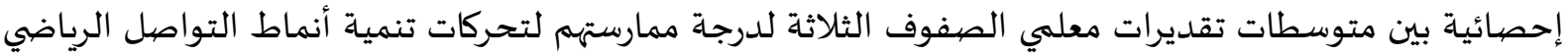

ثانياً دراسـة الفروق وفقاً للمؤهل العلمي: لاختبار دلالة الفروق وفقاً للمؤهل العلمي تم استخدام اختبار نظرا لأن المؤهل العلمي يتألف من ثلاثة مستويات (دكتوراه، ماجستير، بكالوريوس)، وقد استخدم 
الإحصاء اللامعلمي نظرا لعدم تحقق شرط اعتدالية التوزيع الطبيعي للمجموعات حيث تم التحقق من ذلك

باستخدام اختبار Kolmogorov- Smirnov والجدول (9)

جدول (9): اختبار Kruskal- wallis للتعرف على دلالة الفروق وفقاً للمؤهل العلمي

\begin{tabular}{|c|c|c|c|c|c|}
\hline Sig & درجة الحرية & قيمة مريع كاي & متوسط الرتب & $\mathbf{N}$ & 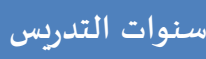 \\
\hline \multicolumn{6}{|c|}{ المححور الأول: استخدام التقنية الحديثة في تدريس الرياضيات } \\
\hline \multirow{3}{*}{0.028} & \multirow{3}{*}{2} & \multirow{3}{*}{7.155} & 59.17 & 84 & بكالوريوس \\
\hline & & & 77.86 & 35 & ماجستير \\
\hline & & & 74.55 & 11 & دكتوراه \\
\hline \multicolumn{6}{|c|}{ المححور الثاني: توظيف استراتيجيات تدريس الرياضيات } \\
\hline \multirow{3}{*}{0.03} & \multirow{3}{*}{2} & \multirow{3}{*}{7.008} & 59.42 & 84 & بكالوريوس \\
\hline & & & 75.41 & 35 & ماجستير \\
\hline & & & 80.36 & 11 & دكتوراه \\
\hline \multicolumn{6}{|c|}{ المححور الثالث: تنظيم وقت تدريس الرياضيات بفاعلية } \\
\hline \multirow{3}{*}{0.007} & \multirow{3}{*}{2} & \multirow{3}{*}{9.978} & 58.18 & 84 & بكالوريوس \\
\hline & & & 78.10 & 35 & ماجستير \\
\hline & & & 81.32 & 11 & 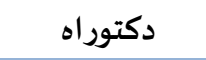 \\
\hline \multicolumn{6}{|c|}{ المحور الرابع: استخدام التواصل الرياضي } \\
\hline \multirow{3}{*}{0.012} & \multirow{3}{*}{2} & \multirow{3}{*}{7.772} & 59.07 & 84 & بكالوريوس \\
\hline & & & 73.89 & 35 & ماجستير \\
\hline & & & 87.91 & 11 & دكتور اه \\
\hline \multicolumn{6}{|c|}{ الاستبانة ككل } \\
\hline \multirow{3}{*}{0.025} & \multirow{3}{*}{2} & \multirow{3}{*}{7.389} & 58.97 & 84 & بكالوريوس \\
\hline & & & 77.64 & 35 & ماجستير \\
\hline & & & 76.73 & 11 & دكتوراه \\
\hline
\end{tabular}

توضح النتائج في جدول (9) أن قيمة p- value أصغر من (050.05) وهذا يشير وجود فرق دال إحصائيا

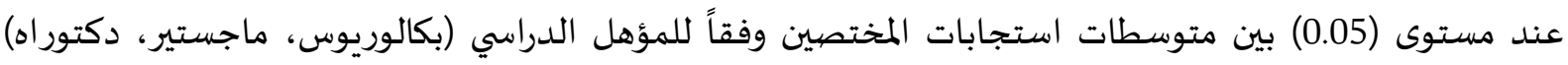

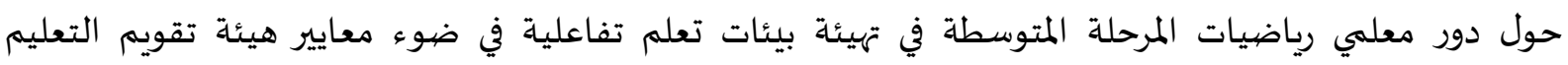

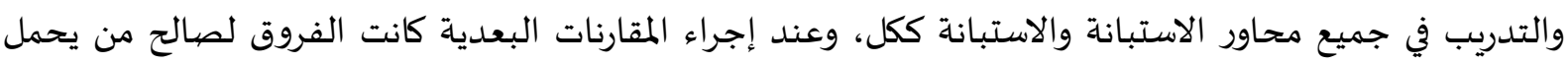

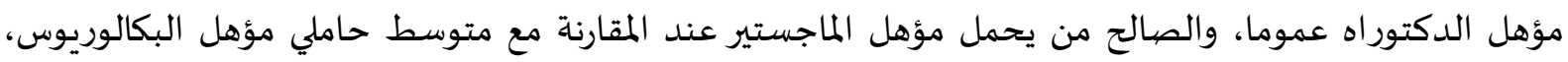

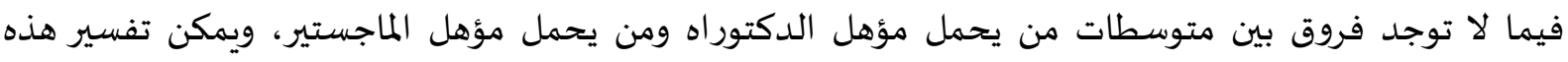

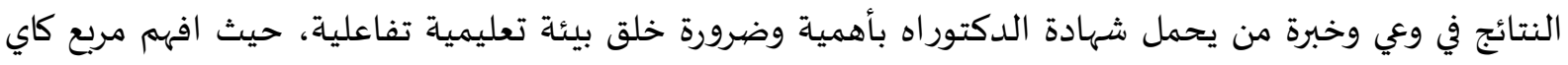
(0.978) (Kruskal- wallis) (0.05) بين متوسطات استجابات المختصين وفقاً للمؤهل الدراسي (بكالوريوس، ماجستير، دكتوراه)، بينما اختلفت

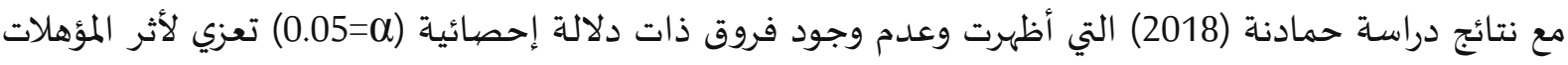
العلمية في جميع المجالات. 
ثالثاً: دراسـة الفروق وفقاً لسنوات الخبرة في تعليم الرياضيات: لاختبار دلالة الفروق وفقا لسنوات الخبرة تم استخدام اختبار Kruskal- wallis بعد التحقق من عدم

تحقق شرط اعتدالية التوزيع للمجموعات، والجدول (10) يوضح النتائج التي حصلنا عليها: جدول (10): اختبار Kruskal- wallis للتعرف على دلالة الفروق وفقاً لسنوات الخبرة

\begin{tabular}{|c|c|c|c|c|c|}
\hline Sig & درجة الحرية & قيمة مريع كاي & متوسط الرتب & $\mathbf{N}$ & 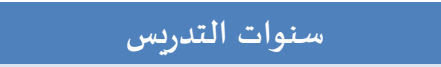 \\
\hline \multicolumn{6}{|c|}{ المحور الأول: استخدام التقنية الحديثة في تدريس الرياضيات } \\
\hline \multirow{3}{*}{0.008} & \multirow{3}{*}{2} & \multirow{3}{*}{9.548} & 76.86 & 22 & أقل من 10 سنوات \\
\hline & & & 74.02 & 46 & من 10 سنوات إلى أقل من 15 سنة \\
\hline & & & 55.15 & 62 & 15 سنة فأكثر \\
\hline \multicolumn{6}{|c|}{ المحور الثاني: توظيف استراتيجيات تدريس الرياضيات } \\
\hline \multirow{3}{*}{0.001} & \multirow{3}{*}{2} & \multirow{3}{*}{14.356} & 80.86 & 22 & أقل من 10 سنوات \\
\hline & & & 74.67 & 46 & من 10 سنوات إلى أقل من 15 سنة \\
\hline & & & 53.24 & 62 & 15 سنة فأكثر \\
\hline \multicolumn{6}{|c|}{ المحور الثالث: تنظيم وقت تدريس الرياضيات بفاعلية } \\
\hline \multirow{3}{*}{0.000} & \multirow{3}{*}{2} & \multirow{3}{*}{17.806} & 80.52 & 22 & أقل من 10 سنوات \\
\hline & & & 76.96 & 46 & من 10 سنوات إلى أقل من 15 سنة \\
\hline & & & 51.67 & 62 & 15 سنة فاكثر \\
\hline \multicolumn{6}{|c|}{ المحور الرابع: استخدام التواصل الرياضي } \\
\hline \multirow{3}{*}{0.001} & \multirow{3}{*}{2} & \multirow{3}{*}{13.863} & 78.34 & 22 & أقل من 10 سنوات \\
\hline & & & 75.98 & 46 & من 10 سنوات إلى أقل من 15 سنـة \\
\hline & & & 53.17 & 62 & 15 سنة فاكثثر \\
\hline \multicolumn{6}{|c|}{ الاستبانة ككل } \\
\hline \multirow{3}{*}{0.001} & \multirow{3}{*}{2} & \multirow{3}{*}{14.858} & 80.57 & 22 & أقل من 10 سنوات \\
\hline & & & 75.82 & 46 & من 10 سنوات إلى أقل من 15 سنة \\
\hline & & & 52.50 & 62 & 15 سنة فأكثر \\
\hline
\end{tabular}

كما أظهرت النتائج أيضا وجود فروق ذات دلالة إحصائية عند مستوى ( 15 ماتر مبن متوسطات الاستجابات حول دور معلمي رياضيات المرحلة المتوسطة في تهيئة بيئات تعلم تفاعلية تعزى لسنوات الخبرة لكل

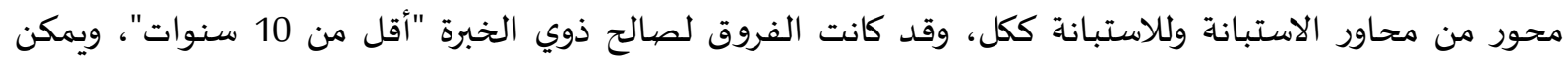

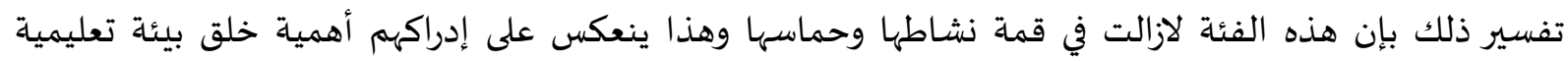

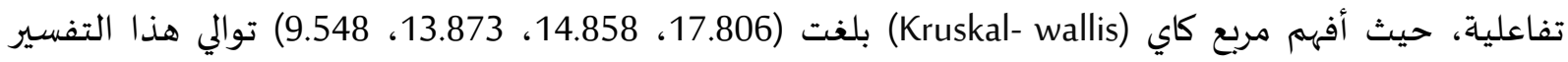
ينسجم مع ما توصلت إليه دراسة العمري (2018) بوجود وجود فرق دال إحصائيا بين استجابات أفراد عينة

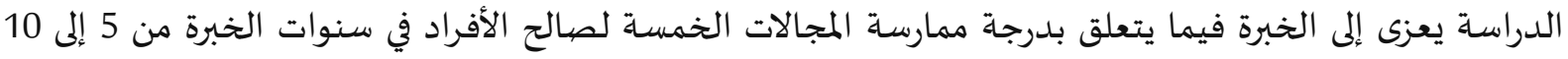

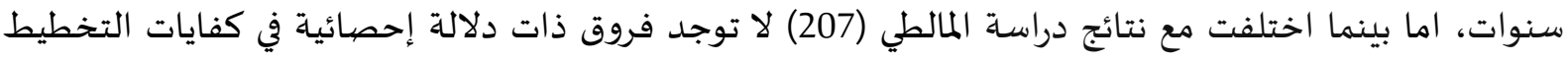
للدروس اليومية لدى معلمي الرياضيات بالشق الثاني من التعليم الأساسي تعزى لمتغير الخبرة.، وهذه النتيجة تتشابهاه

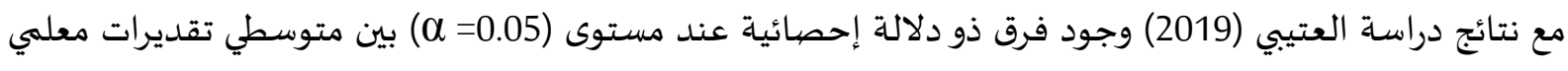

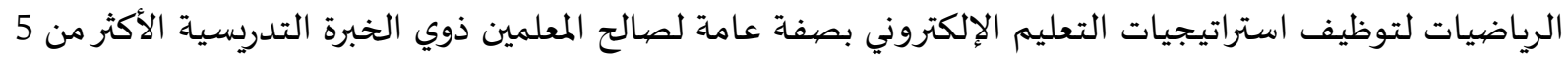


توصيات الدراسـة ومقترحاتها.

1- تزويد المشرفين التربويين التابعين بالتصور المقترح الذي خرج به هذا البحث في سبيل تعزيز بيئة تعليمية

تفاعلية.

2- تفعيل دور معلم الرياضيات في تهيئة بيئات تعلم تفاعلية قائمة على المعايير المهنية نظرا لإدراكهم العالي بأهميتها ودورها في تعليم وتعلم الرياضيات.

3- عقد دورات تدريبية لمعلمي رياضيات في المرحلة المتوسطة تتعلق باستخدام التقنية الحديثة والاستراتيجيات وطرق التدريس الحديثة.

4- حث معلمي المرحلة المتوسطة من خلال المشرفين التربويين باستخدام لغة الرياضيات لتعزيز التواصل الرياضي 5- كما يقتر ح الباحث إجمراء دراسات في الموضوعات الآتية: 1. دراسة تجريبية لتقصي أثر التصور المقترح في تهيئة بيئات تعلم تفاعلية وداعمة لطالب أثناء العملية التعليمية وأثرها على التحصيل الدراسي. تجربه 2. دراسة كيفية عن الممارسات الفعلية لمعلمي المرحلة المتوسطة في تهيئة بيئات تعلم تفاعلية وداعمة لطالب أثناء العملية التعليمية. 3. دراسة المعوقات التي يواجهها معلمو المرحلة المتوسطة في تهيئة بيئات تعلم تفاعلية وداعمة للطالب أثناء العملية التعليمية. قائمة المراجع

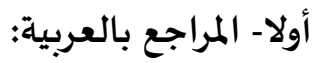
- ال مغني، مشعل بن ثابت (2017). مستوى التنور التقني لدى معلمي الرياضيات بالمرحلة الابتدائية بمحافظة

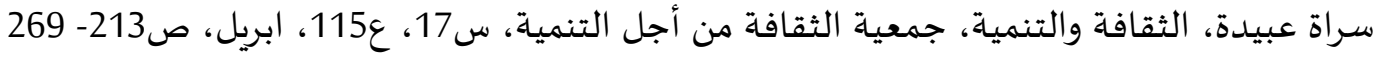

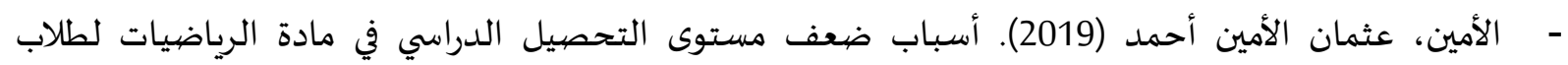

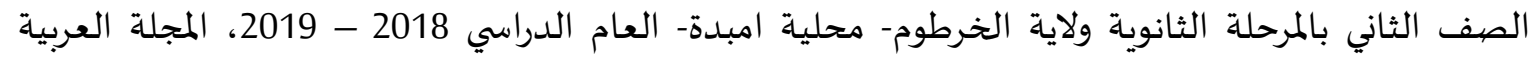
للعلوم التربوية والنفسية، المؤسسة العربية للتربية والعلوم والآداب، ع9، ابريل، 337 337- 360

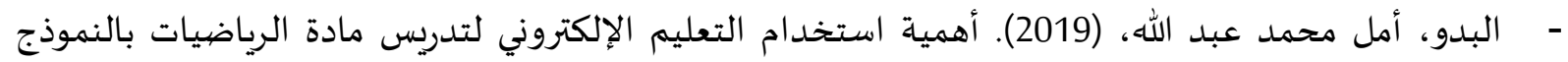
البنائي، المجلة الدولية للبحوث في العلوم التربوية، المؤسسة الدولية لآفاق المستقبل، مج2،ع1، يناير، 159-

- بيومي، ياسر عبد الرحيم، (2019). واقع الممارسات التدريسية الصفية لمعلمي الرياضيات بالمرحلة الابتدائية في ضوء المعايير المهنية المعاصرة لتعليم وتعلم الرياضيات، مجلة تربويات الرياضيات، الجمعية المصرية لتربويات

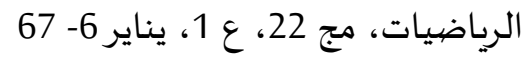
- الجويعد، تهاني بنت عبد الرحمن محمد. (2018). مستوى اداء معلمات الرياضيات بالمرحلة الابتدائية في ضوء ممارسات التدردس المرتكزة على التعلم البنائي بالمملكة العربية السعودية، مجلة تربويات الرياضيات، الجمعية

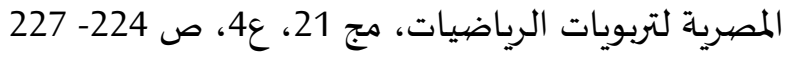


- حلس، ايمن رمضان (2018). فاعلية بيئة تعليمية على مداخل التعليم مهارات التواصل الرياضي لدى الكلبة

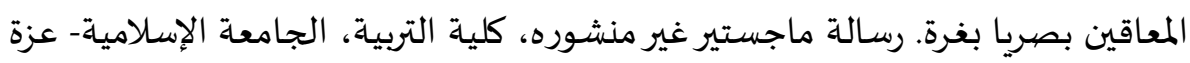

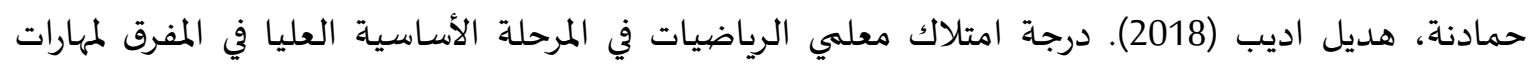
التعلم الإلكتروني ودرجة ممارستهم لها، جامعة ال البيت، كلية العلوم التربوية، 1- 94

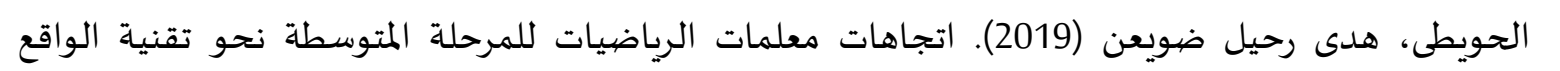

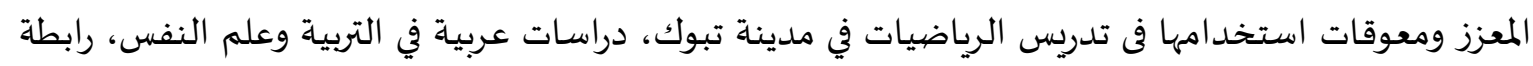

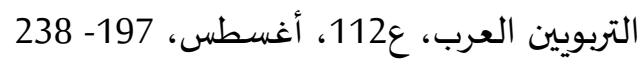

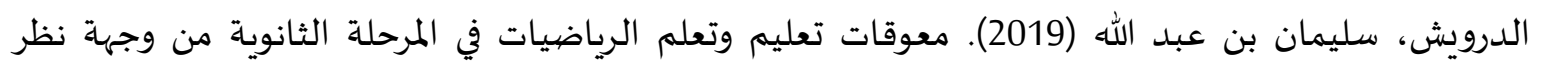
المختصين وطلاب كلية العلوم بجامعة الامام محمد بن سعود الإسلامية، مجلة العلوم التربوية، جامعة الامام

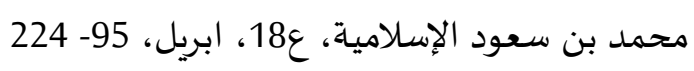
الديب، ماجد حمد (2020). فاعلية استراتيجيات التعلم النشط في تنمية التحصيل ومهارات تدريس الرياضيات

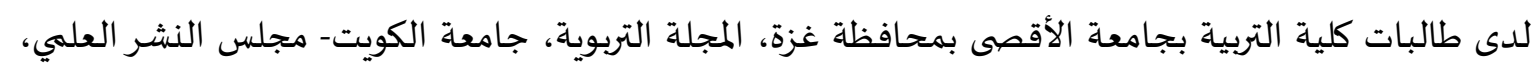

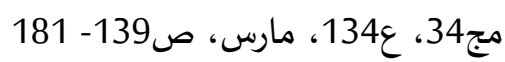

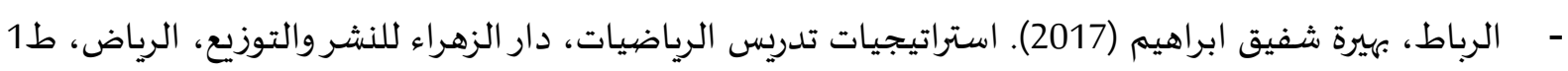

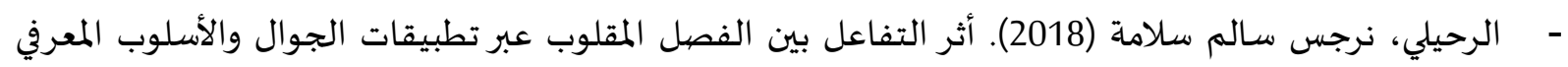

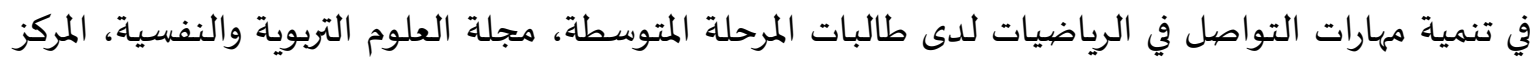
القومى للبحوث غزة، مج 2، ع18، يوليو، 67 م- 94

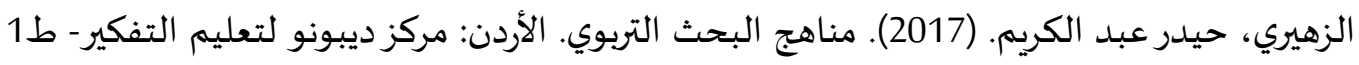

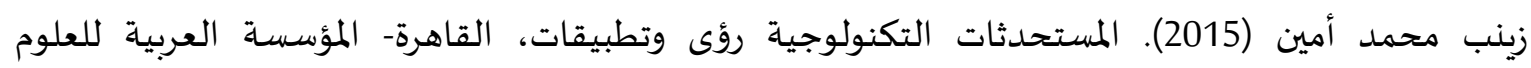

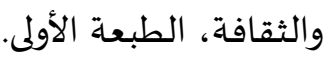
السر، خالد خميس (2015). درجة ممارسة معلمي الرياضيات لتحركات تنمية أنماط التواصل الرياضي ومهاراته

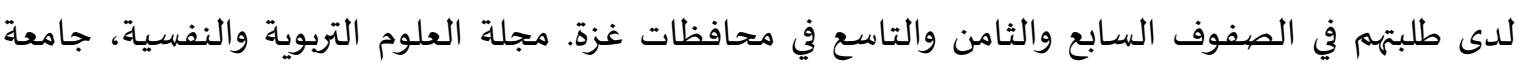

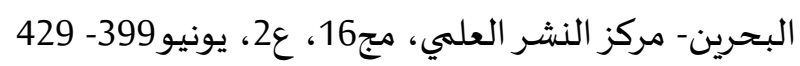
- ـ السلولي، مسفر بن سعود، (2018). العلاقة بين مهارات التواصل الرياضي والتحصيل الدراسي فئي في مقرر

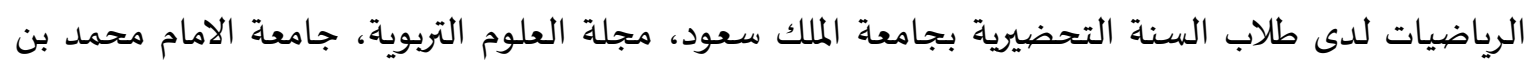
سعود الاسلامية، ع15، يونيو، ص15- 52 سيد، خويدا محمود، (2017). التواصل الرياضي والحس العددي وأساليب تنميتهم برياضيات المرديات المرحلة

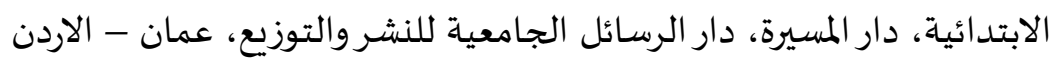
الشاط، امبارك أحمد (2017). بعض الاستراتيجيات الحديثة في تدريس الرياضيات، مؤتمر الرياضيات الأول:

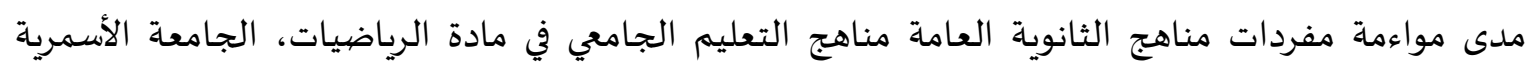
الاسلامية -كلية العلوم، يوليو، 5- مفردات مناهج انونة 32 صيدم، شادي محمد خميس (2017). واقع توظيف معلمي الرياضيات في المرحلة الأساسية بمدارس شرق غزية

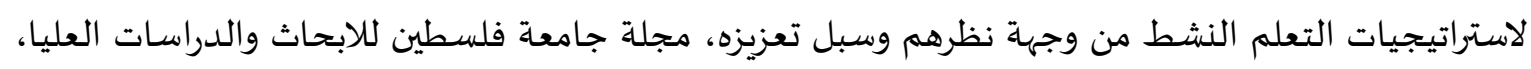

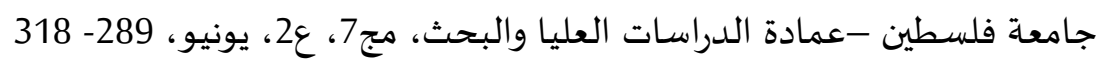


طلبة، محمد علام محمد (2019). فاعلية استخدام الفصل المعكوس في تنمية العمليات المعرفية العليا ومهارات التنظيم الذاتي لتعلم الرياضيات لدى طلاب المرحلة الثانوية. مجلة تربويات الرياضيات، الجمعية المصرية

لتربويات الرياضيات، مج22ع4، ابريل، 151- 212

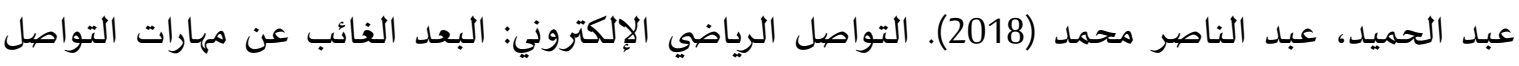

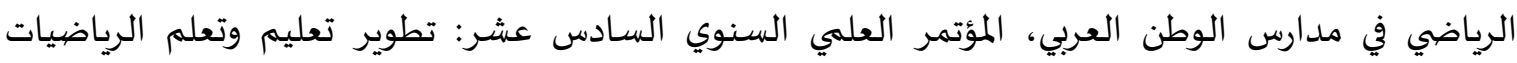

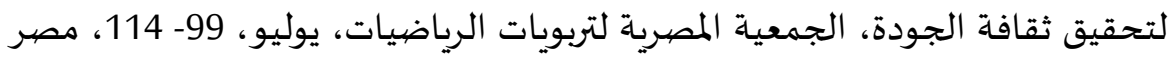
عبد القادر، وخالد فائز، (2015). مهارات إدارة وقت التدريس لدى معلمي الرياضيات بالمرحلة الأساسية العليا

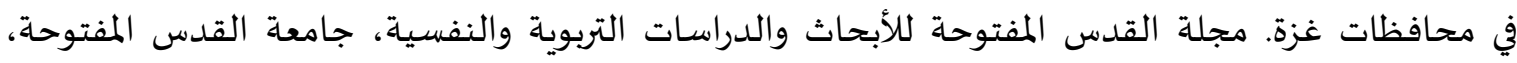
فلسطين، مج 3، ع10، 182- 222 - العتيبي، سلمان بن صاهود راقي (2019). مدى توظيف معلمي الرياضيات بالمرحلتين المتوسطة والثانوية

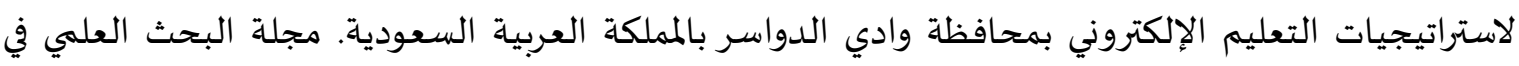

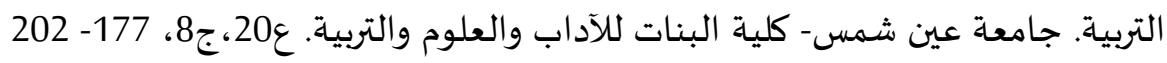

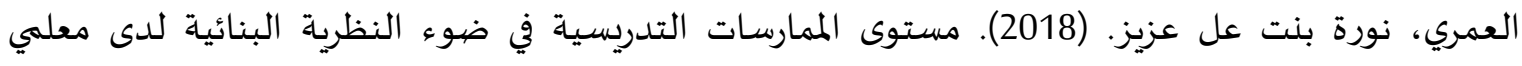

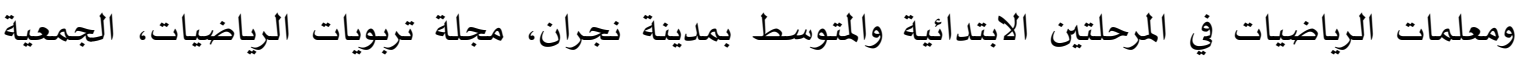
المصرية لتربويات الرياضيات، مج 21، ع 5. 5، 219- 253 العنزي، عبد العزيز بن رواف، (2018). واقع استخدام التقنية في تدريس الرياضيات للمرحلة الابتدائية في

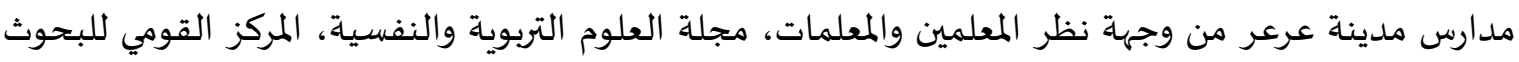

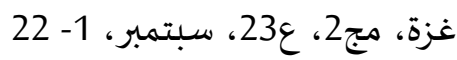
العنزي، مبارك خضر، (2015). أثر استخدام المناقشة في تعلم المفاهيم الرياضية لدى طلاب المرحلة المتوسطة في المملكة العربية السعودية، كلية التربية، جامعة اليرموك، 1- 106

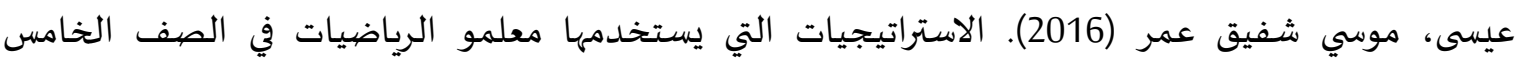
الابتدائي في تدريس المفاهيم الرياضية: دراسة ميدانية محافظة رفح _غزة، مجلة العلوم التربوية، جامعاة

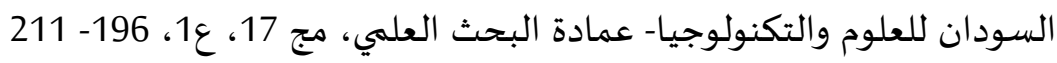

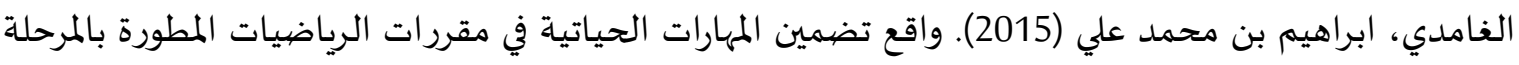

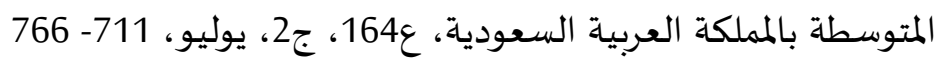

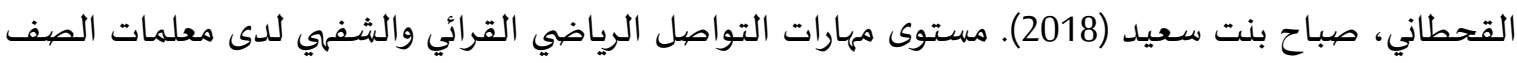

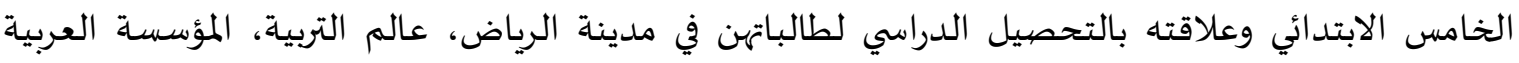

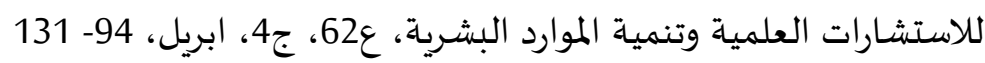

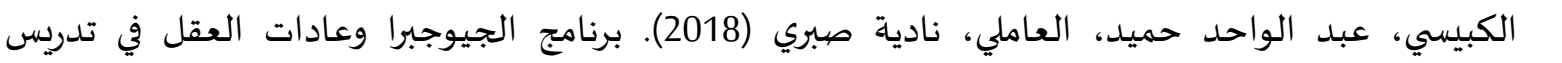

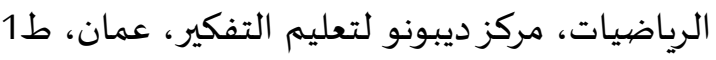
- - كرت، ريم عبد الناصر علي (2019). فاعلية استراتيجية قائمة على المحاكاة الحاسوبية للأشكال الهندسية في في

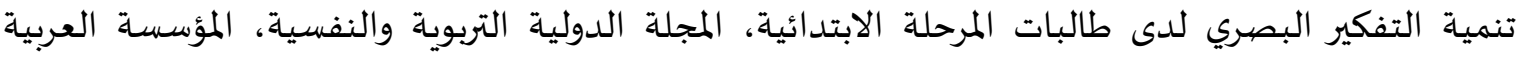

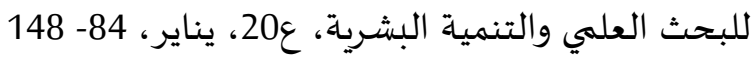


لخضر، شيبوط (2018). التفاعل الصفي وعلاقته بدافعية التعلم لدى طلاب السنة الثالثة ثانوي: دراسة ميدانية بمتقن الشهيد زيان عاشور بمدينة مسعد، مجلة الحكمة للدراسات التربوية ونفسية، مؤسسة كنوز

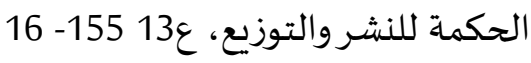
المالطي، محمد عريني سليمان، (2017). مدى إتقان معلمي الرياضيات بالشق الثاني من التعليم الأساسي

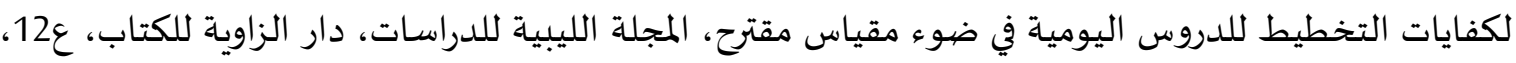

المالكي، عماد عبد الله، (2018). مستوى ممارسات التدريس لدى معلمي الرياضيات بالمرحلة الابتدائية في ضوء معايير تعليم وتعلم الرياضيات، رسالة ماجستير، مجلة تربويات الرياضيات، الجمعية المصيرية لتربويات الرياضيات، مج 21، ع2، ص صديم 135- 160 المالكي، عوض بن صالح. (2015). مستوى أداء معلمي الرياضيات بالمرحلة الابتدائية لبعض الماتهاتهاراتهات اللازمة

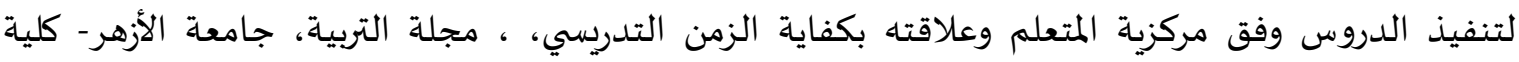
التربية، ع162، ج4، 183 183 223

المرحبي، حسين بن مبارك، (2018). واقع اداء معلمي الرياضيات في المرحلة الابتدائية لمهارات تنفيذ التدريس

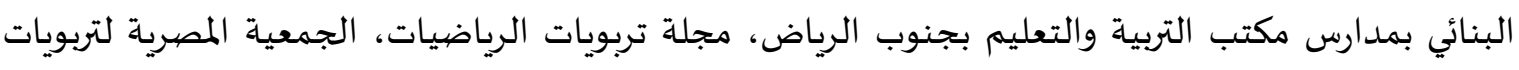

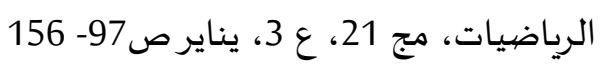
المركز الوطني للقياس (2017). معايير معلمي رياضيات للمرحلتين المتوسطة والثانوية. تم الحصول عليه 2نوفمبر

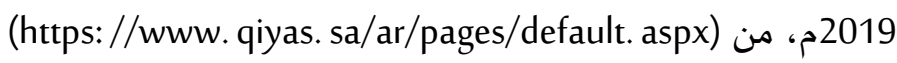
نجم، خميس موسى خميس، (2018). أثر برنامج مقترح لتنمية مهارات الاتصال الرياضي في التحصيل المباشر

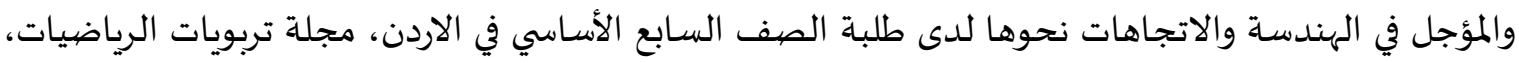

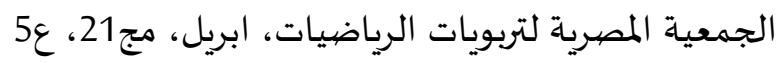
النفيعي، ضواى بن شبيب ضواى (2016). درجة تطبيق معلمي الرياضيات للتعلم النشط، مجلة تربويات

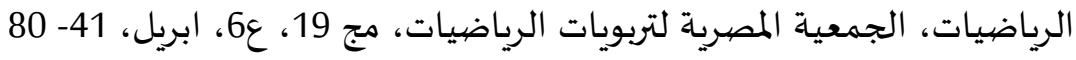
هيئة تقويم التعليم والتدريب (2017). هيئة تقويم التعليم تعتمد المعايير والمسارات المهنية للمعلمين تم

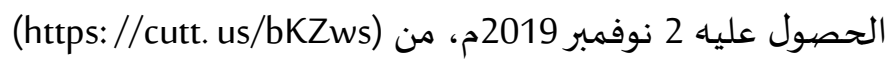

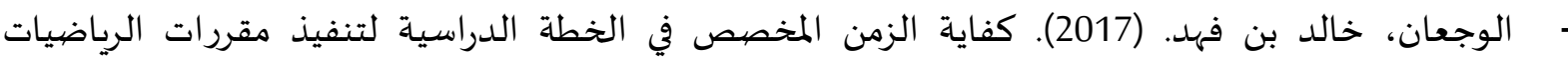

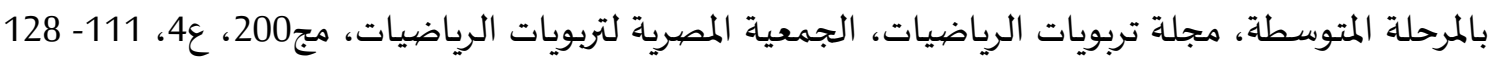

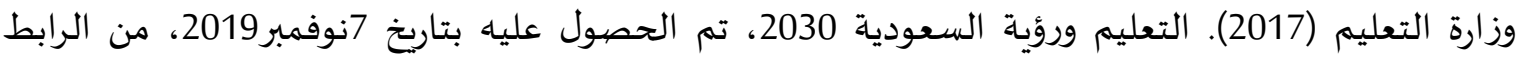
(https://www. moe. gov. sa/ar/Pages/vision2030. aspx)

ثانيا: المراجع الأجنبية:

- Aksu,G,Koruklu,N. (2015). Determination the effects of vocationai high school students logical and critical thinking skills on mathematic success. Eurasian Journal of Educational Research, 59,181- 206

- Enríquez, J. A. V. , de Oliveira, A. M. P. , \& Valencia, H. G. (2018). What Mathematics Teachers Say about the Teaching Strategies in the Implementation of Tasks. English Language Teaching, 11 (1), 6579. 
- Fridha Kusumaningrum, R. (2019). The Relationship between learning time management learning motivation and peer interaction with mathematics learning outcomes in students' class viii of smp negeri. Pandanarum Banjarnegara Regency in odd semester in academic year of 2016/2017 (Doctoral dissertation, University of Ahmad Dahlan).

- Mahmud, M. S. (2019). The Role of Wait Time in the Process of Oral Questioning in the Teaching and Learning Process of Mathematics.

- Murphy. D. (2016). The effect of implementing technology. ina high school mathematics classroom. international journal of Research in Education and Science,2 (2),295- 299

- Oliveira, A. , \& Pombo, L. (2017). Teaching strategies mediated by technologies in the Edulab model: The case of mathematics and natural sciences. International Journal of Research in Education and Science, 3 (1), 88- 106. 